\title{
Spatio-temporal Distribution of Actual Evapotranspiration in the Indus Basin
}

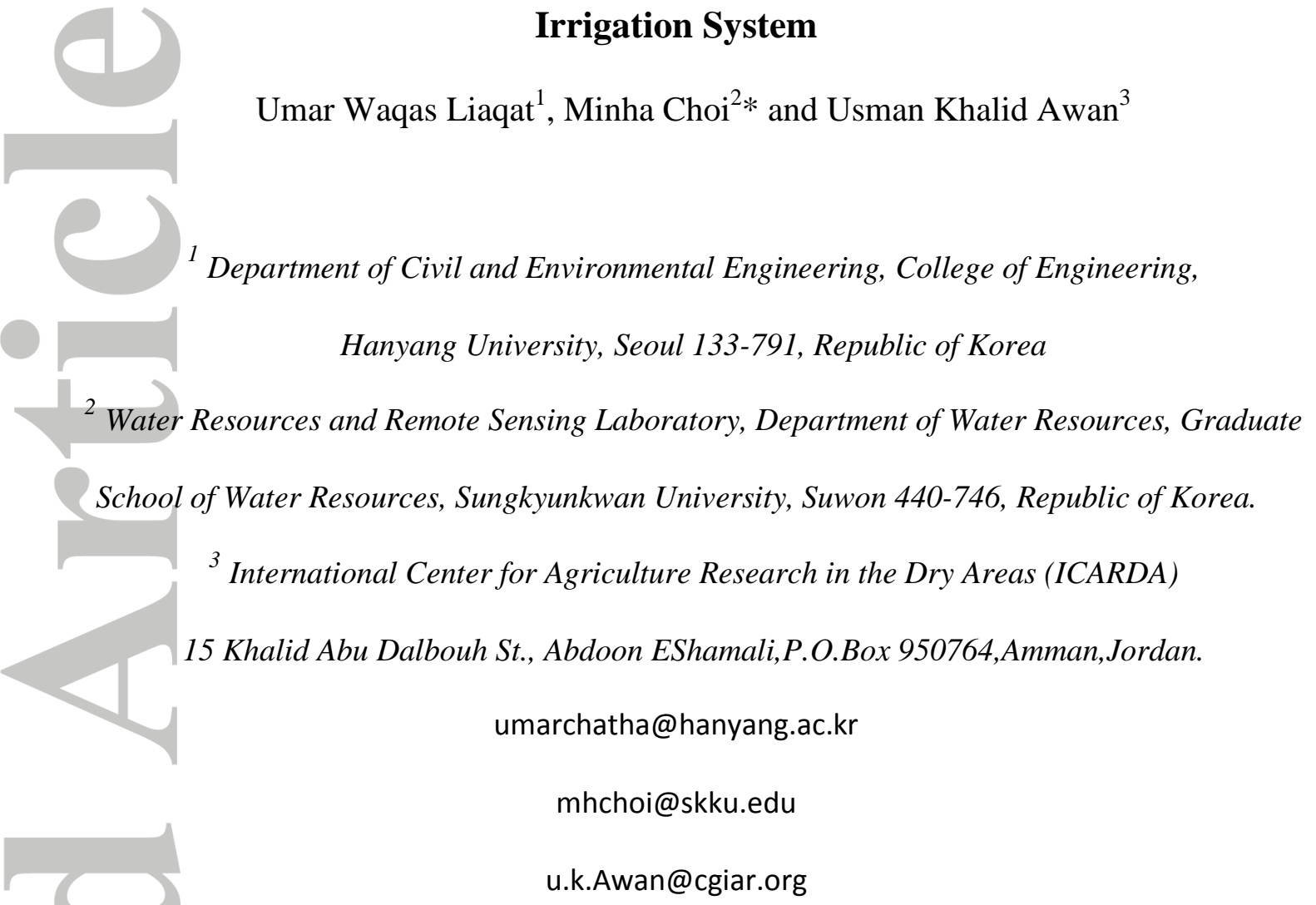

05 Nov 2014

*Corresponding author.

Department of Water Resources, Graduate School of Water Resources

Sungkyunkwan University, Seobu-ro, Jangan-gu, Suwon 440-746, Republic of Korea

Tel: +82- 31- 290-7527,

Fax: +82- 31- 290-7549.

E-mail address: mhchoi@skku.edu

This article has been accepted for publication and undergone full peer review but has not been through the copyediting, typesetting, pagination and proofreading process which may lead to differences between this version and the Version of Record. Please cite this article as doi: 10.1002/hyp.10401 


\begin{abstract}
Strategic planning of optimal water use requires an accurate assessment of actual evapotranspiration $\left(\mathrm{ET}_{\mathrm{a}}\right)$ to understand the environmental and hydrological processes of the world's largest contiguous irrigation networks, including the Indus Basin Irrigation System (IBIS) in Pakistan. The Surface Energy Balance System (SEBS) has been used successfully for accurate estimations of $\mathrm{ET}_{\mathrm{a}}$ in different river basins throughout the world. In this study, we examined the application of SEBS using publically available remote sensing data to assess the spatial variations in water consumption and to map water stress from daily to annual scales in the IBIS. Ground based $\mathrm{ET}_{\mathrm{a}}$ was calculated by the advection-aridity (AA) method, from nine meteorological sites and used to evaluate the intra-annual seasonality in the hydrological year 2009-2010. In comparison with the AA, SEBS computed daily $\mathrm{ET}_{\mathrm{a}}$ was slightly underestimated with a bias of $-0.15 \mathrm{~mm} \mathrm{day}^{-1}$ during the kharif (wet; AprilSeptember) season and it was overestimated with a bias of $0.23 \mathrm{~mm} \mathrm{day}^{-1}$ in the rabi (dry; October-March) season. Monthly values of the $\mathrm{ET}_{\mathrm{a}}$ estimated by SEBS were significantly $(P<0.05)$ controlled by mean air temperature and rainfall, among other climatological variables (relative humidity, sunshine hours, and wind speed). Due to the seasonal (kharif and rabi) differences in the water and energy budget in the huge canal command areas (CCAs) of the IBIS, $\mathrm{ET}_{\mathrm{a}}$ and rainfall were positively correlated in the kharif season and were negatively correlated during the rabi season. In addition, analysis of the evaporation process showed that mixed-cropping and rice-wheat dominated areas had relatively lower and higher water consumption rates, respectively, in comparison with other cropping systems in the basin. Basin areas under water stress were identified by means of spatial variations in the relative evapotranspiration (RET), which had an average value of 0.59 and 0.42 during the kharif and the rabi seasons, respectively. The hydrological parameters used in this study provide useful information for understanding hydrological processes at different spatial and temporal scales.
\end{abstract}


Results of this study further suggest that the SEBS is useful for evaluation of water resources in semi-arid to arid regions over longer time periods, if the data inputs are carefully handled.

Keywords: Actual evapotranspiration, Relative evapotranspiration, Water scarcity, Surface

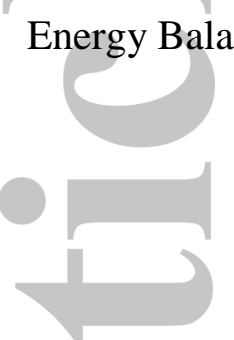

\section{Introduction}

Actual evapotranspiration ( $\left.\mathrm{ET}_{\mathrm{a}}\right)$, including surface evaporation and plant transpiration, is required to understand both hydrological and ecological processes between the land surface and the atmosphere (Hwang and Choi, 2013). Reliable spatio-temporal distribution of $\mathrm{ET}_{\mathrm{a}}$ is crucial to demonstrate the hydrological status of complex landscapes for water resources planning and monitoring, efficient irrigation scheduling, and climate change research (Choi et al., 2009; Matin and Bourque, 2013). Due to complex land-plant-atmosphere interactions and natural variability in topography, soil moisture, and vegetation type, estimation of $\mathrm{ET}_{\mathrm{a}}$ is the most challenging among all of the components of the hydrologic cycle, especially in regions where water is scarce or fluctuates seasonally (Xu and Singh, 2005; Cao et al., 2014).

Several conventional techniques, including weighing lysimeters, the Energy Balance Bowen Ratio (EBBR), scintillometry, and Eddy Covariance (EC) systems, which employ point measurements, have the operational capabilities to provide reasonable values of $\mathrm{ET}_{\mathrm{a}}$ over homogenous surfaces at site level (Sarwar and Bill, 2007). However, these measurements have scientific limitations for providing spatial distributions over a landscape or region due to dynamic land surface heterogeneity, high advective climatic environments, and sparseness of data points (Li et al., 2009; Matin and Bourque, 2013). In order to address this problem, $\mathrm{ET}_{\mathrm{a}}$ measurement using spatial techniques has gained popularity by 
continuously retrieving land surface parameters from operationally available satellite information. The primary benefit of spatial techniques is that $\mathrm{ET}_{\mathrm{a}}$ from the pixel level to basin and regional scales can be estimated directly by using energy balance algorithms rather than by quantifying the other complex hydrological processes which involve detailed information about soil-plant-atmosphere interaction at high spatial and temporal scale (Jia et al., 2009; Hwang and Choi, 2013; Byun et al., 2014). The development, advantages, and limitations, based on how energy balance algorithms combine remotely sensed vegetation indices and radiometric temperatures with ancillary surface measurements, used to estimate $\mathrm{ET}_{\mathrm{a}}$ have been frequently reviewed (Gowda et al., 2008; Li et al., 2009; Liou et al., 2014). The Surface Energy Balance System (SEBS) developed by Su (2002) is a widely accepted and validated algorithm used to derive turbulent heat fluxes and evaporative fractions for hydrological modeling from field to regional scales (Lu et al., 2013; Byun et al., 2014). SEBS is basically a single-source algorithm which uses either the Monin-Obukov Similarity (MOS) theory (Monin and Obukov, 1954) for Atmospheric Surface Layer (ASL) scaling or the Bulk Atmospheric Similarity (BAS) theory (Brutsaert, 1999) for Atmospheric Boundary Layer (ABL) scaling. As the MOS and BAS theories are height dependent, SEBS is more reliable to model $\mathrm{ET}_{\mathrm{a}}$ over complex heterogeneous ecosystems (Jia et al., 2009).

Water cycling in both vapor $\left(\mathrm{ET}_{\mathrm{a}}\right)$ and liquid (rainfall) form is the most pronounced feature in semi-arid to arid irrigated cropland areas of the Indus Basin Irrigation System (IBIS) in Pakistan (Ahmed et al., 2009). The IBIS is among the largest $\left(149,000 \mathrm{~km}^{2}\right)$ and most water deficient contiguous basins in the world, and it is facing a major challenge of limited water resources due to unregulated utilization, inefficient water use, transboundary conflicts, climate change, and rapid urbanization and population growth (Laghari et al., 2012). Water scarcity in the basin has been further accelerated not only because of deep groundwater levels due to over exploitation (Cheema et al., 2014), but also due to complex 
surface water distribution. Irrigated agriculture is classified into various cropping zones that primarily rely on surface water provided through a canal-based irrigation system. This system is extremely valuable due to its good quality water. The area covered by each canal for irrigation supply is known as the canal command area (CCA). However, the distribution of surface water is not uniform among the different CCAs in the IBIS. In the presence of complex cropping systems, inequitable water distribution, and a heterogeneous rainfall pattern, it is difficult to estimate the accurate crop water consumption and its requirement in the IBIS (Ahmed et al., 2009).

In order to address and meet this challenge in such a large basin, comprehensive plans are needed that utilize spatial modeling based on an accurate assessment of $\mathrm{ET}_{\mathrm{a}}$ with user friendly approaches. The few efforts made to quantify $\mathrm{ET}_{\mathrm{a}}$ in the IBIS using combined ground measurements and remote sensing information after various preprocessing complexities, have described contrasting levels of accuracy in the final $\mathrm{ET}_{\mathrm{a}}$ product (Bastiaanssen et al., 2002; Sarwar and Bill, 2007; Bastiaanssen et al., 2012). Evaluation of hydrological processes relies on in-situ hydrological data that is not only hard to access in different parts of the world (e.g., Central Asia), but data quality is often questionable (Awan et al., 2011).

In the current study, we therefore utilized the SEBS algorithm to map the spatio-temporal variations of $\mathrm{ET}_{\mathrm{a}}$ (April 2009-March 2010) by combining freely and readily available Moderate Resolution Imaging Spectroradiometer (MODIS) remote sensing imagery and meteorological information from the Global Land Data Assimilation System (GLDAS). Ground based $\mathrm{ET}_{\mathrm{a}}$ values calculated using the Advection-Aridity method from nine meteorological stations were used to evaluate and assess the physical plausibility of the SEBS results. The effects of different climatological variables on the variations in monthly $\mathrm{ET}_{\mathrm{a}}$ values were also analyzed. Seasonal and annual patterns of water consumption $\left(\mathrm{ET}_{\mathrm{a}}\right)$ and 
crop water requirements (potential evapotranspiration, i.e., $\mathrm{ET}_{\mathrm{p}}$ ) were assessed with special emphasis on the cropping zone and the canal command areas (CCAs) in the complex landscape of the IBIS. By combining the above steps with a sensitivity analysis, this study demonstrates a pathway to the processes responsible for variations in the components of water cycling under specific hydro-meteorological conditions.

\section{Study area}

This study was conducted in the IBIS in Pakistan, which lies between latitude $24.14^{\circ}$ to $34.46^{\circ}$ North and longitude $67.41^{\circ}$ to $74.68^{\circ}$ East (Figure 1). The IBIS encompasses approximately $149,000 \mathrm{~km}^{2}$ in three major provinces, Punjab, Sindh and Khyber Pakhtunkhwa (KPK) with five rivers flowing across the region that deliver water to the 44 canal command areas (CCAs). It is the most productive river basin globally currently supporting approximately $22 \%$ of the country's gross domestic product (down from approximately 27\% in 1989; Yu et al., 2013). The basin area is further categorized into seven different cropping zones (Figure 1) based on land use cropping patterns and climatic conditions shown in Table 1 (Ullah et al., 2001). The two most unique cropping seasons in the region are the kharif (wet; summer) season, which occurs from April to September with rice, cotton, and maize as the major crops, and the rabi (dry; winter) season, which occurs from October to March with wheat and fodder as the dominant crops. Surface topography in the basin gradually decreases from $250 \mathrm{~m}$ above mean sea level in the upper north of the basin to less than five $\mathrm{m}$ above mean sea level, except for the northwest-cropping zone where the average elevation is higher than $300 \mathrm{~m}$ above mean sea level. The prevailing climate is semi-arid to arid with extreme variations in temperature and rainfall depending upon topography (Ahmed et al., 2009).

Rainfall and reference evapotranspiration $\left(\mathrm{ET}_{\mathrm{o}}\right)$, important components of hydrological processes, can vary significantly during different years. Therefore, rainfall and $\mathrm{ET}_{\mathrm{o}}$ values 
during the study period (April 2009-Mar 2010) were compared to average values for the last 30 years (1980-2010; Figure 2). Monthly reference evapotranspiration (ET ${ }_{0}$ ) was estimated from 1980 to 2010 using the Penman-Monteith method (Allen et al., 1998). Data required to estimate $\mathrm{ET}_{\mathrm{o}}$ includes relative humidity, wind speed, solar radiation, and minimum and maximum temperatures. This data and rainfall data was obtained from the Pakistan Meteorological Department (PMD). Ranges of maximum and minimum temperatures were approximately $22-44^{\circ} \mathrm{C}$ and $5-28^{\circ} \mathrm{C}$, respectively, throughout the year (Figure 2). Annual average rainfall in the region was $336 \mathrm{~mm}$ (1980-2010), of which $240 \mathrm{~mm}$ and $96 \mathrm{~mm}$ was observed during the Kharif and the rabi seasons, respectively. Almost 50\% and 30\% less rainfall occurred during the reported study period in the kharif and the rabi seasons, respectively. Monthly $\mathrm{ET}_{\mathrm{o}}$ values during the study period ranged from 65-277 mm, which were slightly higher than the historical values that ranged from 51-270 mm.

\section{Material and Methods}

\subsection{MODerate-resolution Imaging Spectroradiometer (MODIS) data}

Satellite data, including the land surface temperature (LST), land surface albedo, and vegetation indices, are key surface variables in the SEBS formulation for dividing available energy between soil and vegetation. MODIS level 3 readily available standard products (Table 2) with $1 \mathrm{~km}^{2}$ spatial resolution for 94 cloud-free days between April 2009 and March 2010 were selected from the NASA online web portal (http://ladsweb.nascom.nasa.gov/data/). Broadband surface emissivity is an essential parameter for deriving total surface net radiation. Currently, there are not many alternatives available to obtain surface emissivity data except for deriving this information from the daily narrow band emissivity provided by the MODIS level 1 data available from bands 29, 31, and 32 (Su et al., 2007; McCabe et al., 2011). It should be noted that the MODIS level 3 data was already atmospherically corrected and ready to use, while the MODIS level 1 data was 
preprocessed and corrected atmospherically before final use (Figure 3). The MODIS combined Aqua + Terra Albedo product (MCD43B3), contains two different sets of data, including black-sky and white-sky albedo. However, there is no true land surface albedo product. Therefore, in order to provide a reasonable approximation, the averaged value of black- and white-sky albedo was utilized (Su et al., 2007). Leaf area index (LAI) and normalized difference vegetation index (NDVI) are key factors that drive the ecophysiological processes to determine the water and heat exchanges between land and the atmosphere. Jia et al. (2009) stated that these land surface properties (NDVI, LAI, and albedo) do not change considerably during short time periods. The MODIS LST data was collected instantaneously at the satellite overpass time with a daily time step.

\subsection{Global Land Data Assimilation System data}

The Global Land Data Assimilation System (GLDAS) is a comprehensive integration of ground and satellite observations in order to generate near real time fields of land surface states (Rodell et al., 2004). GLDAS originally belonged to the land information system (LIS)-modeling framework operated by various community land surface models in the hydrological sciences branch of NASA's Goddard Space Flight Center. Currently, GLDAS data is widely used and validated for land surface modeling, specifically when data is scarce or in ungauged basins due to its easy accessibility (Su et al., 2007; McCabe et al., 2011). GLDAS data simulated from the Noah 2.7.1 land surface model (Marshall et al., 2013) contains a series of land surface parameters at a spatial resolution of $0.25^{\circ}$ with 3-hour time step information (GLDAS_NOAH025SUBP_3H). In order to force the SEBS algorithm, meteorological variables (Table 2), including specific humidity $\left(\mathrm{kgkg}^{-1}\right)$, wind speed $\left(\mathrm{ms}^{-1}\right)$, air pressure $(\mathrm{Pa})$, air temperature $\left({ }^{\circ} \mathrm{C}\right)$, and downward long-wave and incident short-wave radiation $\left(\mathrm{Wm}^{-2}\right)$, were extracted from the Goddard Earth Sciences Data and Information Services Center (GES DISC) website (http://disc.sci.gsfc.nasa.gov/hydrology). All 
meteorological variables were linearly interpolated between 0600 and 0900 Coordinated Universal Time (UTC) in order to match the temporal resolution with MODIS overpass time.

Datasets with different spatial scales were resampled in space by using the nearest neighbor interpolation method with MODIS Reprojection Tool (https://lpdaac.usgs.gov/tools/modis_reprojection_tool) to obtain the final ET a products of 1 $\mathrm{km}^{2}$ resolution (Byun et al., 2014).

\subsection{Surface Energy Balance System (SEBS) for estimating actual evapotranspiration}

The Surface Energy Balance System (SEBS) originally developed by Su (2002), is a single- source formulation fundamentally based on the energy balance equation in limiting cases (dry and wet). It is a well-established image processing algorithm used to compute atmospheric turbulent heat fluxes, evaporative fraction, and $\mathrm{ET}_{\mathrm{a}}$ from remote sensing observations (van der Kwast et al., 2009; Muthuwatta et al., 2010; Rwasoka et al., 2011; Lu et al., 2013; Byun et al., 2014). In this study, SEBS was forced using atmospherically corrected MODIS image products and routine weather parameters obtained from GLDAS (Table 2) during a complete cropping year (April 2009-March 2010). Figure 3 presents the processing of this dataset to estimate pixel by pixel instantaneous $\mathrm{ET}_{\mathrm{a}}$ from the residual surface energy budget equation, which is expressed as follows:

$$
\lambda E=R_{N}-G-H
$$

where $\lambda E$ is the turbulent latent heat flux $\left(\mathrm{W} \cdot \mathrm{m}^{-2}\right)$ connected to the moisture transfer into the atmosphere, $R_{N}$ is net radiation $\left(\mathrm{W} \cdot \mathrm{m}^{-2}\right), G$ is soil heat flux $\left(\mathrm{W} \cdot \mathrm{m}^{-2}\right)$, and $H$ is turbulent sensible heat flux $\left(\mathrm{W} \cdot \mathrm{m}^{-2}\right)$. The difference between short-wave and long-wave radiation fluxes at the land surface gives an $R_{N}$ value as follows:

$$
R_{N}=(1-\alpha) \cdot R_{\text {sd }}+R_{l d}-R_{l u}
$$

where $\alpha$ is the surface albedo, $R_{s d}$ is downward short-wave radiation $\left(\mathrm{W} \cdot \mathrm{m}^{-2}\right)$, and $R_{l d}$ 
is downward long-wave radiation $\left(\mathrm{W} \cdot \mathrm{m}^{-2}\right)$. These parameters values were derived from MODIS and GLDAS datasets (Table 2), while $R_{l u}$ upward long-wave radiation $\left(\mathrm{W} \cdot \mathrm{m}^{-2}\right.$ ) was estimated in the form of $R_{l u}=\varepsilon \cdot \sigma \cdot T_{s}^{4}$, where $\varepsilon$ is surface emissivity, $\sigma$ is StefanBoltzmann constant $\left(\mathrm{W} \cdot \mathrm{m}^{-2} \cdot \mathrm{K}^{-4}\right)$, and $T_{s}$ is land surface temperature $(\mathrm{K})$. Soil heat flux $(G)$ for SEBS was empirically determined as a fraction of $G / R_{N}$ using fractional canopy coverage, which was linearly interpolated between bare soil and full vegetation canopy conditions (Su, 2002). Similarity theory was used to estimate sensible heat flux $(H)$ in order to derive latent heat flux ( $\lambda E$ ) in Eq. (1) as a residual term. Depending on the height at which the measurements were taken, SEBS uses either the MOS theory (Monin and Obukov, 1954) for ASL scaling or the BAS theory (Brutsaert, 1999) for ABL scaling. In this study, all measurements were conducted within the ASL. The MOS theory was considered for allocation of $H$ from available energy through an iteration procedure (Su, 2002) as follows:

$$
\begin{gathered}
u=\frac{u_{*}}{k} \times\left[\ln \left(\frac{z-d_{0}}{z_{0 m}}\right)-\psi_{m}\left(\frac{z-d_{0}}{L}\right)+\psi_{m}\left(\frac{z_{0 m}}{L}\right)\right] \\
\theta_{s}-\theta_{a}=\frac{H}{k u_{*} \rho C_{p}}\left[\ln \left(\frac{z-d_{0}}{z_{0 h}}\right)-\psi_{h}\left(\frac{z-d_{0}}{L}\right)+\psi_{h}\left(\frac{z_{0 h}}{L}\right)\right]
\end{gathered}
$$

where $u$ is wind speed $(\mathrm{m} / \mathrm{s}), u_{*}$ is friction velocity $(\mathrm{m} / \mathrm{s}), \quad k=0.4$ is von Karman's constant, $d_{0}$ is zero-plan displacement height $(m), z$ is reference height above the surface (m), $L$ is Monin-Obukhov length $(\mathrm{m}), z_{0 m}$ is the roughness height for momentum transfer (m), $z_{0 h}$ is scalar height for the height transfer (m), and $\psi_{m}$ and $\psi_{h}$ are the stability correction functions for momentum and sensible heat transfer, respectively. In addition, $\rho$ is air density $\left(\mathrm{kg} / \mathrm{m}^{3}\right), C_{p}$ is specific heat for moist air $(\mathrm{J} / \mathrm{kg} . \mathrm{K})$, and $\theta_{s}$ and $\theta_{a}$ are potential temperature $(\mathrm{K})$ of the surface and air at the reference height, respectively. A further 
detailed interpretation of the equations and a discussion of the similarity theory can be found in Su (2002) and Byun et al. (2014). In SEBS, the estimated $H$ was constrained between dry limit $\left(H_{d r y}\right)$ and wet limit $\left(H_{\text {wet }}\right)$ values. Under dry-limit conditions, latent heat $\left(\lambda E_{d r y}\right)$ became zero due to limited soil moisture availability where $H$ reached its maximum value and could be directly derived as follows:

$$
H_{d r y}=R_{N}-G_{0}
$$

(5)

Conversely, under wet-limit conditions, $\lambda E$ reached its maximum value due to no limitation of available water and evapotranspiration took place at a potential rate limited only by available energy, while $H$ took its minimum value. At this stage, $H_{\text {wet }}$ was determined by using combination equation similar to the Penman-Monteith equation (Monteith, 1965) and after Su (2002), it is expressed as follows:

$$
H_{\text {wet }}=\left(\frac{\left(R_{N}-G_{0}\right)-\frac{\rho C_{p}}{r_{e w}} \times \frac{e_{s}-e_{a}}{\gamma}}{1+\frac{\Delta}{\gamma}}\right)
$$

where $e_{s}$ and $e_{a}$ are saturation and actual vapor pressures, respectively, $\gamma$ is psychometric constant, $\Delta$ is the slope of the saturated water vapour pressure curve at the current temperature, and $r_{e w}$ is the external resistance at wet limit. After deriving the three sensible heat flux $(H)$ values, actual $H$ was scaled in a range set between $H_{\text {wet }}$ and $H_{d r y}$ under limiting cases. Finally, scaled $H$ was incorporated into Eq. (1) in order to compute instantaneous values of $\lambda E$, relative evaporation $\left(\Lambda_{r}\right)$, and then the evaporative fraction (EF), which expresses the ratio of actual evaporation to total available energy as follows:

$$
\Lambda=\frac{\lambda E}{R_{N}-G}=\frac{\Lambda_{r} \cdot \lambda E_{w e t}}{R_{N}-G}
$$


EF $(\Lambda)$ is known to be conservative in a diurnal cycle and can be assumed to be representative of daily energy partitioning during cloud-free conditions (Ahmad et al., 2009; Jia et al., 2009). Therefore, instantaneous $\Lambda$ at the satellite overpass time was used to compute instantaneous $\mathrm{ET}_{\mathrm{a}}$ and then scaled up to daily values, $\mathrm{ET}_{24}(\mathrm{~mm} /$ day), by estimating averaged 24-h net radiation $\left(R_{N 24}\right.$; Jia et al., 2009). For further extrapolation of $\Lambda$ to monthly, seasonal, and annual timescales, the Bastiaanssen et al. (2002) approach was used. The basic concept in this formulation, Eq. (8), was that $\Lambda$ remains almost constant between successive cloud-free images. Satellite observations at frequent intervals, usually less than 20 days, were sufficient to estimate accumulated $\mathrm{ET}_{\mathrm{a}}$ and acceptable results were reported in previous studies (Farah et al., 2004; Ahmed et al., 2009; Muthuwatta et al., 2010; Awan et al., 2011). In this study, the interval was varied between 2-10 days (for approximately $90 \%$ of the data) for cloud-free MODIS image acquisitions (a total of 94) between April 2009 and March 2010, except for 2 instances when the intervals were 21 and 24 days during the monsoon season due to constant cloud-cover. For $\mathrm{ET}_{\text {int; }}$;

$$
E T_{\text {int }}=\frac{d t \times 86,400 \times 10^{3}}{\lambda \rho_{w}} \cdot \Lambda \cdot R_{N 24 t}
$$

where $\mathrm{ET}_{\text {int }}\left(\mathrm{mm} /\right.$ interval) is $\mathrm{ET}_{\mathrm{a}}$ for the time interval $d t$ measured in days and $R_{N 24 t}$ is the average $R_{N 24}$ value over the same time interval, which is usually $R_{N 24 t}<R_{N 24}$, due to the addition of cloudy days, $\lambda$ is latent heat of vaporization $\left(2.47 \times 10^{6} \mathrm{~J} \cdot \mathrm{kg}^{-1}\right)$, and $\rho_{w}$ is density of water $\left(\mathrm{kg} \cdot \mathrm{m}^{-3}\right)$. 


\subsection{Advection-Aridity evapotranspiration method for validating the SEBS algorithm}

In the absence of direct measurement of evaporative fraction or $\mathrm{ET}_{\mathrm{a}}$ in the field, the advection-aridity (AA) method originally proposed by Brutsaert and Stricker (1979) was used in this study to evaluate the SEBS estimated $\mathrm{ET}_{\mathrm{a}}$. Several researchers have used the AA method in different formats to enumerate $\mathrm{ET}_{\mathrm{a}}$ in various climatic settings and found reasonable agreement when compared with eddy covariance measurements or water balance approaches (Xu and Singh, 2005; Liu et al., 2006; Matin and Bourque, 2013). Shifa (2011) used the AA method in wet and dry climatic conditions of Spain, and reported that $\mathrm{ET}_{\mathrm{a}}$ estimated by the AA method at hourly and daily time steps had good agreement with eddy covariance measured $\mathrm{ET}_{\mathrm{a}}$. Liu et al. (2006) used three different complementary relationship approaches to map regional $\mathrm{ET}_{\mathrm{a}}$ in China and concluded that $\mathrm{AA}$ is the most accurate method, showing the least mean relative error of less than $5 \%$ in comparison with that from the water balance method. Previous studies also used the AA method to evaluate $\mathrm{ET}_{\mathrm{a}}$ estimated by the energy balance algorithm in the absence of field measurements (Rwasoka et al., 2011; Usman et al., 2014). The AA method by Brutsaert and Stricker (1979) used the Priestley-Taylor (P-T) equation (Priestley-Taylor, 1972) for wet surface evapotranspiration $\left(\mathrm{ET}_{\mathrm{w}}\right)$ [expressed by Eq. (9)], the Penman (1956) equation for potential evapotranspiration $\left(\mathrm{ET}_{\mathrm{p}}\right)$ [Eq. (10)], and an empirical wind function $f\left(\mathrm{u}_{2}\right)$ for determination of relative evaporation [ $E_{r}$; Eq. (11)] as follows:

$$
\begin{gathered}
E T_{w}=\alpha_{e} \frac{\Delta}{\Delta+\gamma}\left(R_{N}-G\right) \\
E T_{p}=\frac{\Delta}{\Delta+\gamma}\left(R_{N}-G\right)+\frac{\gamma}{\Delta+\gamma} \times E_{r} \\
E_{r}=f\left(\mathrm{u}_{2}\right) \times\left(e_{s}-e_{a}\right)
\end{gathered}
$$


where $\left(R_{N^{-}}-G\right)$ is net available energy at the surface, $\alpha_{e}=1.26$ is the P-T coefficient, $\Delta$ is the slope of saturated water vapor pressure curve at the current air temperature $\left(\mathrm{kPa}^{\circ} \mathrm{C}^{-1}\right), \quad \gamma$ is psychometric constant $\left(\mathrm{kPa}^{\circ} \mathrm{C}^{-1}\right), f\left(\mathrm{u}_{2}\right)$ is estimated in the form of $f\left(\mathrm{u}_{2}\right)=0.26\left(1+0.54 \mathrm{u}_{2}\right)$

, $\mathrm{u}_{2}$ is mean wind speed $\left(\mathrm{ms}^{-1}\right)$ at $2 \mathrm{~m}$ above the ground surface, and $e_{a}$ and $e_{s}$ are actual and saturation vapor pressures, respectively. Brutsaert and Stricker (1979) combined Eqs. (9) through (11) based on the complementary relationship between $\mathrm{ET}_{\mathrm{p}}$ and $\mathrm{ET}_{\mathrm{a}}$ introduced by Bouchet (1963) as follows:

(12)

$$
E T_{a}=\left(2 \alpha_{e}-1\right) \frac{\Delta}{\Delta+\gamma}\left(R_{N}-G\right)-\frac{\Delta}{\Delta+\gamma} \times 0.26\left(1+0.54 u_{2}\right) \times\left(e_{s}-e_{a}\right)
$$

Meteorological data obtained from the PMD was used to force the AA method in order to calculate in-situ $\mathrm{ET}_{\mathrm{a}}$ over nine different weather stations (Figure 1) during the same period (April 2009-March 2010). The value of $R_{N}$ in Eq. (12) was computed by Eq. (2) using point measurements from weather stations and assuming a surface albedo value of 0.23 (Allen et al., 1998). In addition, we computed the seasonal gridded $\mathrm{ET}_{\mathrm{w}}$ using the P-T method, which became equal to $\mathrm{ET}_{\mathrm{p}}$ when available surface moisture was unlimited. For the P-T method in Eq. (9), the inverse distance weighted (IDW) technique was used to interpolate climatic data from weather stations, while the spatial distributions of remote sensing albedo (Table 2) were utilized to derive the $R_{N}$ values.

\section{Results and Discussion}

\subsection{Performance comparison of the SEBS algorithm and the AA method}

For the accuracy assessment, SEBS estimated daily $\mathrm{ET}_{\text {a }}$ pixel values that geographically corresponded to the nine weather stations (Figure 1) in the IBIS were extracted and compared with $\mathrm{ET}_{\mathrm{a}}$ derived using the AA method. A reasonable correlation between daily $\mathrm{ET}_{\mathrm{a}}$ (for cloud-free days) of SEBS and AA, yielding coefficients of determination $\left(\mathrm{R}^{2}\right)$ of 0.70 and 
0.61 , with bias errors of $-0.15(-2.85 \%) \mathrm{mm} \mathrm{day}^{-1}$ and $0.23(11.40 \%) \mathrm{mm} \mathrm{day}^{-1}$, and a root mean square error (RMSE) of $0.76 \mathrm{~mm} \mathrm{day}^{-1}$ and $0.39 \mathrm{~mm}$ day $^{-1}$ during the kharif (wet) and the rabi (dry) seasons, respectively (Figure 4). Bias error was determined by subtracting $\mathrm{ET}_{\mathrm{a}}$ of AA from SEBS estimations, so that negative and positive biases corresponded to underand over-estimation of SEBS in comparison to the AA method, respectively. Generally, the comparison revealed that SEBS estimations tracked the AA calculations fairly well, but $\mathrm{ET}_{\mathrm{a}}$ from both of the approaches deviated slightly more from the 1:1 correspondence line for extreme high and low values. This result was due to the fact that SEBS $\operatorname{ET}_{\mathrm{a}}$ was derived by solving the energy budget equation $\left(\lambda E=R_{N}-G-H\right)$ and therefore, the high spatial variability $\left(25 \mathrm{~km}^{2}\right)$ of the GLDAS meteorological input data could cause distortions in the estimated energy fluxes. In addition to the meteorological factors, the difference in the spatial scale of $\mathrm{ET}_{\mathrm{a}}$ estimates for SEBS and AA could cause some errors in the comparisons. Bastiaanssen et al. (2012) reported similar problems with spatial scale when comparing the Surface Energy Balance Algorithm for Land (SEBAL) results with lysimeter values. The AA method performed worse during extreme wet and dry environmental conditions. Liu et al. (2006) mentioned that methods based on complementary relationships usually underestimated $\mathrm{ET}_{\mathrm{a}}$ in humid conditions, while overestimating in arid conditions. A similar inconsistency was reported for the complementary relationship approaches such as the AA method, which used the minimum data in order to derive $\mathrm{ET}_{\mathrm{a}}$ in comparison with energy balance approaches (Rwasoka et al., 2011; Usman et al., 2014). Usman et al. (2014) used the SEBAL model with MODIS data to estimate $\mathrm{ET}_{\mathrm{a}}$ for a small watershed in the IBIS and found percentage biases of $-24.89 \%$ and $-13.32 \%$ in comparison with the AA method during the summer (April-September) and winter (October-March) seasons, respectively. Nevertheless, SEBS performance in this study was also comparable with previous studies in which remote sensing land surface parameters were combined with GLDAS meteorological information (Su 
et al., 2007; McCabe et al., 2011; Byun et al., 2014).

\subsection{Effect of climate variables on monthly actual evapotranspiration}

SEBS estimated daily evaporative fraction could be integrated at appropriate intervals using Eq. (8). Mean monthly $\mathrm{ET}_{\mathrm{a}}$ estimated by Eq. (8) is presented in Figure 5 along with variations in the basic meteorological variables across the IBIS. Table 3 shows the results of the linear correlation between the meteorological variables and $\mathrm{ET}_{\mathrm{a}}$ with a significance level of 0.05 (p-value). Variation in $\mathrm{ET}_{\mathrm{a}}$ ranged between $33 \mathrm{~mm}$ (December) and $152 \mathrm{~mm}$ (July) and was in accordance with the trends of mean monthly air temperature and rainfall volumes (Figure 5a). The highest $\mathrm{ET}_{\mathrm{a}}$ during July was due to the prominent monsoon season in which nearly $65 \%$ of the total annual rainfall occurred with high mean air temperatures values. However, in spite of some of the rainfall amounts, the lowest values in the month of December were primarily due to reduced available energy (Ullah et al., 2001). Significant results $(p<0.05$ : Table 3 ) for temperature and rainfall reflected the hydro-meteorological characteristics of the region and showed that $\mathrm{ET}_{\mathrm{a}}$ variation was largely dependent on variation of both of these variables. Both factors could directly affect the water demand and supply, in order to convert a water scarce area (rainfall $<\mathrm{ET}_{\mathrm{a}}$ ) into a water production area (rainfall $\left.>\mathrm{ET}_{\mathrm{a}}\right)$. A high positive correlation $\left(\mathrm{R}^{2}=0.86\right.$ : Table 3 ) between the air temperature and $\mathrm{ET}_{\mathrm{a}}$ depicted the existence of high surface energy potential in the region which maximally supported the highest vapor transport process.

Wind speed (Figure 5b) was another factor contributing to high $\mathrm{ET}_{\mathrm{a}}$ during the summer (April-September) with a declining contribution during winter (October-March). Overall, no significant correlation $\left(\mathrm{R}^{2}=0.17\right.$ : Table 3$)$ was found between wind speed and $\mathrm{ET}_{\mathrm{a}}$ for the study period. The wind speed involved in the aerodynamic resistance calculations and any changes in its values were central to changes in evaporative demand. Fluctuations in wind speed were directly connected to roughness through vegetation (Bichet et al., 2012) and 
diversity of vegetation structure in the IBIS, due to a variety of land uses and land cover types (Cheema et al., 2010) which could cause larger variability in $\mathrm{ET}_{\mathrm{a}}$.

Relative sunshine duration and relative humidity did not fully correspond to $\mathrm{ET}_{\mathrm{a}}$ variations (Figure 5c). Relative sunshine duration was associated with daily available energy and its variation could be described by cloud-free and cloudy conditions (Liu et al., 2010). The effects of relative sunshine duration were not significant showing the least correlation $\left(\mathrm{R}^{2}=0.01\right.$ : Table 3$)$ with changes in $\mathrm{ET}_{\mathrm{a}}$ among all of the tested variables. This was primarily due to its relatively minor variation range during the study period. Relative humidity, linked with vapor pressure deficit was close to the 0.05 significance level and was negatively correlated $\left(\mathrm{R}^{2}=0.32\right.$ : Table 3) with $\mathrm{ET}_{\mathrm{a}}$. A large fluctuation in relative humidity values during the summer period was slightly more influencing to the estimated $\mathrm{ET}_{\mathrm{a}}$ (Figure 5c). Both factors, relative sunshine duration and relative humidity, which are believed to have a strong influence (Ren et al., 2012; Cao et al., 2013), showed inferior impact to monthly ETa computed using the SEBS (Table 3). This result clearly demonstrated that the impact of relative sunshine duration and relative humidity was altered by mean air temperature, which was the most dominant factor that controlled $\mathrm{ET}_{\mathrm{a}}$ in the IBIS.

\subsection{Seasonal and annual evapotranspiration and deriving variables}

Satellite based spatio-temporal calculations can provide useful information in order to determine variability in water equity, i.e., net water production (Rainfall $>\mathrm{ET}_{\mathrm{a}}$ ) or water consumption (Rainfall $<\mathrm{ET}_{\mathrm{a}}$ ). The monthly maps of $\mathrm{SEBS}_{\mathrm{ET}}$ and rainfall (interpolated) were summed and a summary of mean seasonal and annual values were obtained through a spatial overlay analysis in Geographic Information System (GIS). Mean ETa and rainfall across the various canal command areas (CCAs) ranged between 536-874 mm and 60-414 mm during the kharif season, 222-380 $\mathrm{mm}$ and 13-202 mm during the rabi season, and 854$1208 \mathrm{~mm}$ and 99-596 mm on an annual basis, respectively (Figure 6). When $\mathrm{ET}_{\mathrm{a}}>$ rainfall, 
irrigation water is supplied by surface water or pumped ground water (Cheema et al., 2014). From a hydrological prospective, diversity in the rainfall pattern along with inconsistent water supplies (Ahmad et al., 2009), and unstable ground water quality + availability (Cheema et al., 2014) caused larger fluctuations in $\mathrm{ET}_{\mathrm{a}}$ across the CCAs. Areas located near primary rivers or at the head of canals usually received high water supplies, which gradually decreased towards the tail-enders (Ahmad et al., 2009). Therefore, CCAs located in Punjab showed comparatively smooth results for $\mathrm{ET}_{\mathrm{a}}$ during both seasons (kharif and rabi) in spite of larger variations in rainfall, due to their greater proximity to surface water and good quality ground water (Cheema et al., 2014). High variability in $\mathrm{ET}_{\mathrm{a}}$ across the CCAs in the Sindh and KPK provinces, specifically during the kharif season, reflected their dependence on rainfall rather than surface or ground water access. The relatively dry conditions prevailing during the 2009 kharif season (Yu et al., 2013) were due to 50\% less rainfall than the long-term average value, which consequently produced high temporal variability in $\mathrm{ET}_{\mathrm{a}}$. Spatial variability in $\mathrm{ET}_{\mathrm{a}}$ is shown (Figure 6) by means of standard deviation (error bars). Low error bars around mean value across each of the CCAs depicts that water use was remained more consistent during the rabi season than in comparison with the kharif season which showed relatively higher standard deviation values.

Larger variability during the kharif season was attributed to higher availability of surface energy with variations in surface soil moisture across the basin. A scatter plot comparison between seasonal mean $\mathrm{ET}_{\mathrm{a}}$ and rainfall values showed a negative correlation during the rabi season and a positive correlation during the kharif season (Figure 7). For the rabi season, $\mathrm{ET}_{\mathrm{a}}$ generally decreased with an increase in rainfall because of energy limitations which were caused by a decrease in air temperature. However, $\mathrm{ET}_{\mathrm{a}}$ gradually increased with an increase in rainfall during the kharif season because of high air temperature which positively influenced energy and water budgets (Cao et al., 2013). 
Seasonal and annual distributions of $\mathrm{ET}_{\mathrm{a}}$ were not only impacted by water and energy distribution, but also by crop water demand and cultivation patterns that were dominated by different cropping systems in the IBIS (Ullah et al., 2001). Results of seven different cropping zones showed large differences in $\mathrm{ET}_{\mathrm{a}}(\mathrm{SEBS}), \mathrm{ET}_{\mathrm{p}}(\mathrm{P}-\mathrm{T})$, and rainfall, with annual ranges of 853-1168 mm, 1788-1967 mm and 123-481 mm, respectively (Table 4). Low $\mathrm{ET}_{\mathrm{a}}$ values in the mixed-cropping zone $\left(14,000 \mathrm{~km}^{2}\right)$ were primarily caused by cultivation of food and fruit crops that are less water intensive, and by high seepage due to presence of sandy soils (Ullah et al., 2001). Similarly, annual $\mathrm{ET}_{\mathrm{a}}$ values were higher in the rice-wheat cropping system, which covers approximately $43,000 \mathrm{~km}^{2}$ in the IBIS of Pakistan. The primary reason for these higher values is related to farming water management practices for rice. Rice crops are ponded in standing water by farmers during the entire growing season in order to maximize rice crop yield (Usman et al., 2014). This results in larger $\mathrm{ET}_{\mathrm{a}}$ values annually. The difference between $\mathrm{ET}_{\mathrm{a}}$ and rainfall $\left(\mathrm{ET}_{\mathrm{a}}-\mathrm{P}\right)$ varied between 479-844 mm (Table 4) and implies that locally occurring rainfall minimally supported the high water demands of irrigated agriculture in the IBIS.

It has been reported in different studies that availability of surface and groundwater supplies is expected to be reduced in coming years (Qurashi et al., 2010; Cheema et al., 2014). Relative evapotranspiration (RET) measured as $E T_{a} / E T_{p}$ can be an important strategic indicator to identify areas that are suffering from water resources scarcity. Figure 8 shows the seasonal spatial distribution of RET, illustrating a strong seasonality due to contrasting cropping patterns and climatic conditions. Values of RET varied between 0.080.77 and $0.12-0.61$ and had average values between 0.59 and 0.42 during the kharif and the rabi seasons, respectively. For the Punjab rice-wheat cropping zone, Ahmed et al. (2009) reported a 0.6 RET value under similar climatic characteristics. Most of the areas located in Punjab and KPK showed relatively greater and uniform RET values during both seasons due 
to higher agricultural land coverage and greater proximity to surface water. A RET of less than 0.2 was prominent in tail-ender areas or where cropping intensities were low with sandy soil types, such as the Punjab mixed cropping zone (Ullah et al., 2001). As RET is related to a water deficiency against potential crop water demands, a value of 0.8 , which ensured sufficient soil moisture for evapotranspiration processes under less water stress and maximized crop production, is generally assumed ideal (Awan et al., 2011). Wheat is one of the major crops in the rabi season sown on more than 55\% of the total IBIS (Khan et al., 2008). A mean RET in study areas was $48 \%$ less than the target values (0.8). This shows water scarcity in the region which illustrates water management flaws in irrigation schemes. However, proper utilization of rainfall in the kharif season can further increase soil moisture availability (i.e., RET) during rice growing periods.

\subsection{Sensitivity analysis of the SEBS algorithm}

A sensitivity analysis was conducted in order to investigate the role of important parameters on SEBS performance, to constrain errors and increase robustness. In general, uncertainties in input parameterization are largely associated with inherent errors in satellite data and with the processing of image data (Gibson et al., 2011; Byun et al., 2014). Several authors have reported various types of SEBS sensitivities to input data (Badola, 2009; van der Kwast et al., 2009; Gibson et al., 2011; Wang et al., 2013). Recently, Abdelrady (2013) reported that sensible heat flux $(H)$ is more sensitive to atmospheric variables than vegetation indices. Badola (2009) concluded that vegetation indices, including LAI and NDVI values, had no significant effects on daily $\mathrm{ET}_{\mathrm{a}}$ in the SEBS algorithm. In this study, sensitivity analysis of fundamental climate variables, including land surface temperature $\left(T_{s}\right)$ and land surface albedo derived from MODIS, as well as air temperature $\left(T_{a}\right)$ and wind speed derived from GLDAS, was conducted to examine the impact of variation in these climatological variables on the estimated $\mathrm{ET}_{\mathrm{a}}$ by SEBS. $T_{s}$ and $T_{a}$ changed between $-10-10 \mathrm{~K}$ with a step of 
$1 \mathrm{~K}$ from their base values, while wind speed and albedo values were changed from -20-20\% with a step of $2 \%$. Changes in each variable were made individually while keeping the other parameters at their base values. Although selection of day of year (DOY) for sensitivity analysis is irrelevant due to fixed variations in climatological variables, crop growth stages were considered for the selection of DOY-133 for analysis. Responses in SEBS outputs to variation in these parameters are presented in Figure 9.

Relative change in $T_{s}$ and $T_{a}$ from -4-10 K caused approximate differences of 13--58\% and $16--49 \%$ in estimated daily $\mathrm{ET}_{\mathrm{a}}$ from its base value, respectively (Figure 9a). Since the SEBS algorithm works on the principle of extreme limiting conditions (i.e. dry and wet limits), for this particular case, the wet limit was attained only when both $T_{s}$ and $T_{a}$ were decreased to approximately $-4 \mathrm{~K}$ from their base values. After reaching the wet limit, $\mathrm{ET}_{\mathrm{a}}$ remained constant with a further decrease in $T_{a}$ and showing a gradual decrease from 13 to 8\% with a decrease in $T_{s}$ from -4 to $-10 \mathrm{~K}$. The $\mathrm{ET}_{\mathrm{a}}$ decrease was associated with $H$ calculation at the wet limit condition [Eq. (6)], where net radiation $\left(R_{N}\right)$ depended on $T_{s}$. Overall, the changes in $T_{s}$ and $T_{a}$ from -4 to $10 \mathrm{~K}$ within the extreme limits caused a linear variation in the instantaneous $H$ from -41 to $152 \%$ and -50 to $158 \%$ [Eq. (4)], respectively (Figure 9b). A further decrease in $T_{s}$ beyond the wet limit (-4--10 K) increased $H$ from -41 to $-20 \%$, while it remained constant when $T_{a}$ was changed. Independent from extreme limits, instantaneous $R_{N}$ decreased linearly by approximately 10 to $-12 \%$ by changing $T_{s}$ from -10 to $10 \mathrm{~K}$ from its base values, while $T_{a}$ had no effect on estimated $R_{N}$ (Figure $9 \mathrm{~b}$ ). Generally, between the extreme limits, our results showed similar trends with those of previous studies (van der Kwast et al., 2009; Gibson et al., 2011). However, beyond extreme conditions (wet limit), this study extended the findings of Gibson et al. (2011) and Wang et al. (2013) to highlight the need for changes in algorithm formulation. The extreme limits are the boundary conditions where energy balance parameters should become constant and, in this study, the 
errors obtained beyond the wet limit were physically not feasible, specifically in optimal and dry moisture conditions. The results between the extreme limits imply that both the $T_{s}$ and $T_{a}$ are almost equally sensitive to energy balance components causing relatively larger errors in daily $\mathrm{ET}_{\mathrm{a}}$. These temperatures are involved in all stages of the SEBS algorithm for estimating total surface energy budget (Gibson et al., 2011) and, therefore, any erroneous data inputs may lead to ambiguous results of the final $\mathrm{ET}_{\mathrm{a}}$ product. This also implies that their realistic consequence may occur in semi-arid to arid areas, such as the IBIS, where the mean air temperature significantly affects $\mathrm{ET}_{\mathrm{a}}$.

Wind speed is one of the crucial climate variables in the SEBS algorithm. It is used for the determination of various terms including roughness height for momentum and heat transfer, which are related to aerodynamic resistance in $H$ calculation. Figure 9c depicts changes of -20 to $20 \%$ in wind speed which led to linear errors in $H$ from -11.4 to $11.4 \%$. This consequently produced an error of 3.4--3.4\% in daily $\mathrm{ET}_{\mathrm{a}}$. van der Kwast et al. (2009) also reported an approximately -8 to $8 \%$ difference in estimated $H$ with a -25 to $25 \%$ variation in wind speed from field measurements. These minor errors were in an acceptable range when compared with those obtained from $T_{s}$ and $T_{a}$. However, the change in wind speed was central to the change in the eddy diffusivity, which, in turn, altered the evaporative demand (Cao et al., 2013). Fluctuation in wind speed was convoluted and generally associated with surface roughness controlled by vegetation characteristics (Bichet et al., 2012). As SEBS solves a set of complex equations between height of the canopy and displacement to estimate roughness parameters, the relationship between wind speed at reference height and various land cover types in heterogeneous underlying surface environments needs to be explored.

Broadband surface albedo is normally utilized to determine the primary source of energy, i.e., instantaneous $R_{N}$ and daily net radiation, $R_{N 24}$. Estimated $R_{N}$ is used to derive $G$ and $\lambda E$, 
and to estimate $H$ at extreme limits (dry and wet) as described earlier, while $R_{N 24}$ is an essential factor for scaling up the instantaneous evaporative fraction $(\Lambda)$ to daily $\mathrm{ET}_{\mathrm{a}}$. Figure 9d reveals that $R_{N}, R_{N 24}$, and $\mathrm{ET}_{\mathrm{a}}$ linearly decreased from 4.5--4.5\%, 5--5\%, and 6-6\% by changing the base albedo value from -20 to $20 \%$, respectively. Slightly higher inaccuracy in $\mathrm{ET}_{\mathrm{a}}$ was produced from the combined effects of $R_{N}$ and $R_{N 24}$. These errors were not higher than those reported in the literature (Badola 2009). However, it should be noted that an uncertainty in the albedo may cause errors in $H$ through $R_{N}$ at extreme limits, which could ultimately lead to erroneous results of the daily energy budget throughout the process in the SEBS algorithm. Surface albedo is generally affected by solar zenith angle, soil moisture status, and vegetation cover (Oguntunde, 2004), which indicates that any misparameterization of albedo may produce variation in $\mathrm{ET}_{\mathrm{a}}$, specifically in extreme dry or wet land conditions.

\section{Conclusions}

The results of the present study showed that the publically available remote sensing, MODIS, and GLDAS data are useful for tracking aerial changes in water consumption $\left(\mathrm{ET}_{\mathrm{a}}\right)$ and water stress (RET) when in-situ surface or near surface measurements are incomplete or not reliable. The single-source energy balance algorithm (SEBS) is capable of estimating daily $\mathrm{ET}_{\mathrm{a}}$ fairly well as produced by the complementary relationship approach (AA), which uses minimum ground measurements. However, SEBS estimations were slightly lower than the AA calculation (-0.15 mm day ${ }^{-1}$ ) during the kharif (wet; April- September) season and were higher $\left(0.23 \mathrm{~mm} \mathrm{day}^{-1}\right)$ in the rabi (dry; October-March) season. SEBS daily $\mathrm{ET}_{\mathrm{a}}$ estimations were further integrated in space and time in order to capture spatio-temporal variations in $\mathrm{ET}_{\mathrm{a}}$ over large heterogeneous areas such as the IBIS. Among the basic climatological factors, mean air temperature followed by rainfall significantly $(P<0.05)$ affected variations in monthly $\mathrm{ET}_{\mathrm{a}}$, while relative humidity showed a downward tendency, 
which indicated that $\mathrm{ET}_{\mathrm{a}}$ in the IBIS is controlled by the mutual effects of water and energy budgets. Due to seasonal differences in water and energy balance, rainfall positively impacted $\mathrm{ET}_{\mathrm{a}}$ in the kharif season and it showed a negative correlation with $\mathrm{ET}_{\mathrm{a}}$ during the rabi season in the huge canal command areas (CCAs) of the IBIS. Generally, the difference between $\mathrm{ET}_{\mathrm{a}}$ and rainfall $\left(\mathrm{ET}_{\mathrm{a}}-\mathrm{P}\right)$ revealed that locally generated rainfall is insufficient to support irrigated agriculture as the entire IBIS fits with a net water consumptive $(E T>P)$ region. Spatially, the consumptive water use (i.e., $\mathrm{ET}_{\mathrm{a}}$ ) varies depending upon water distribution, diversity in cropping systems and crop water demands. Seasonal spatial distribution of RET identified areas under high water stress. A mean RET of approximately $48 \%$ less than the ideal value (0.8) during the rabi season indicated serious threats to the future sustainability of essential food crops for a rising population. In order to address and mitigate water scarcity issues at the basin scale under a changing climate, an understanding of socio-economic factors at a field scale is important to take into consideration. Aside from these daunting challenges for economic development and livelihood, the hydrological facts quantified by SEBS are vital for the understanding of both water cycling and regional water resources management. However, accurate data inputs and careful processing are essential to take full advantage of SEBS, as basic climatic variables involved in its algorithm composition are sensitive to various energy budget parameters.

\section{Acknowledgments}

This research was supported by Space Core Technology Development Program through the National Research Foundation of Korea (NRF) funded by the Ministry of Science, ICT and Future Planning (NRF-2014M1A3A3A02034789). The first author was supported through a grant by the Higher Education Commission (HEC), Pakistan. 


\section{References}

Abdelrady AR. 2013. Evaporation over fresh and saline water using SEBS. MSc Thesis, University of Twente. The Netherlands.

Ahmad M, Turral H, Nazeer A. 2009. Diagnosing irrigation performance and water productivity through satellite remote sensing and secondary data in a large irrigation system of Pakistan. Agricultural Water Management, 96: 551-564.

Allen RG, Pereira LS, Raes D, Smith M. 1998. Crop evapotranspiration-Guidelines for computing crop water requirements-FAO Irrigation and drainage paper 56. FAO, Rome, 300: 6541.

Awan UK, Tischbein B, Conrad C, Martius C, Hafeez M. 2011. Remote sensing and hydrological measurements for irrigation performance assessments in a water user association in the Lower Amu Darya River Basin. Water Resources Management, 25: 2467-2485.

Badola A. 2009. Validation of Surface Energy Balance System (SEBS) over forest land cover and sensitivity analysis of the model. MSc Thesis, University of Twente, The Netherlands.

Bastiaanssen W, Cheema M, Immerzeel W, Miltenburg I, Pelgrum H. 2012. Surface energy balance and actual evapotranspiration of the transboundary Indus Basin estimated from satellite measurements and the ETLook model. Water Resources Research, 48. DOI: 10.1029/2011WR010482.

Bastiaanssen WG, Ahmad MuD, Chemin Y. 2002. Satellite surveillance of evaporative depletion across the Indus Basin. Water Resources Research, 38. DOI: 10.1029/2001WR000386.

Bichet A, Wild M, Folini D, Schär C. 2012. Causes for decadal variations of wind speed over land: Sensitivity studies with a global climate model. Geophysical Research Letters, 39.

Bouchet R. 1963. Evapotranspiration réelle et potentielle, signification climatique, International Association of Hydrological Sciences, In: Proceedings of General Assembly. California Symposium Publication, Berkely, California. 132-142.

Brutsaert W, Stricker H. 1979. An advection-aridity approach to estimate actual regional evapotranspiration. Water Resources Research, 15: 443-450. 
Brutsaert W. 1999. Aspects of bulk atmospheric boundary layer similarity under free-convective conditions. Reviews of Geophysics, 37: 439-451.

Byun K, Liaqat UW, Choi M. 2014. Dual-model approaches for evapotranspiration analyses over homo-and heterogeneous land surface conditions. Agricultural and forest meteorology, 197: 169-187.

Cao G, Han D, Song X. 2014. Evaluating actual evapotranspiration and impacts of groundwater storage change in the North China Plain. Hydrological Processes, 28: 1797-1808.

Cheema M, Bastiaanssen W. 2010. Land use and land cover classification in the irrigated Indus Basin using growth phenology information from satellite data to support water management analysis. Agricultural Water Management, 97: 1541-1552.

Cheema M, Immerzeel W, Bastiaanssen W. 2014. Spatial quantification of groundwater abstraction in the Irrigated Indus Basin. Groundwater, 52: 25-36.

Choi M, Kustas WP, Anderson MC, Allen RG, Li F, Kjaersgaard JH. 2009. An intercomparison of three remote sensing-based surface energy balance algorithms over a corn and soybean production region (Iowa, US) during SMACEX. Agricultural and forest meteorology, 149: 2082-2097.

Farah H, Bastiaanssen W, Feddes R. 2004. Evaluation of the temporal variability of the evaporative fraction in a tropical watershed. International journal of applied earth observation and geoinformation, 5: 129-140.

Gibson L, Münch Z, Engelbrecht J. 2011. Particular uncertainties encountered in using a prepackaged SEBS model to derive evapotranspiration in a heterogeneous study area in South Africa. Hydrology and Earth System Sciences, 15: 295-310.

Gowda PH, Chavez JL, Colaizzi PD, Evett SR, Howell TA, Tolk JA. 2008. ET mapping for agricultural water management: present status and challenges. Irrigation science, 26: 223-237.

Hwang K, Choi M. 2013. Seasonal trends of satellite-based evapotranspiration algorithms over a complex ecosystem in East Asia. Remote sensing of environment, 137: 244263.

Jia L, Xi G, Liu S, Huang C, Yan Y, Liu G. 2009. Regional estimation of daily to annual regional evapotranspiration with MODIS data in the Yellow River Delta wetland. Hydrology and Earth System Sciences, 13: 1775-1787. 
Khan AH, McCornick P, Khan AR. 2008. Evolution of managing water for agriculture in the Indus River Basin. In: Fighting Poverty Through Sustainable Water Use: Proceedings of the CGIAR Challenge Program on Water and Food, Bayot et al. (ed.) CGIAR Challenge Program on Water and Food, pp: 120-123.

Laghari A, Vanham D, Rauch W. 2012. The Indus basin in the framework of current and future water resources management. Hydrology and Earth System Sciences, 16: 10631083.

Li Z-L, Tang R, Wan Z, Bi Y, Zhou C, Tang B, Yan G, Zhang X. 2009. A review of current methodologies for regional evapotranspiration estimation from remotely sensed data. Sensors, 9: 3801-3853.

Liou Y-A, Kar SK. 2014. Evapotranspiration Estimation with Remote Sensing and Various Surface Energy Balance Algorithms-A Review. Energies, 7: 2821-2849.

Liu C, Liu X, Zheng H, Zeng Y. 2010. Change of the solar radiation and its causes in the Haihe River Basin and surrounding areas. Journal of Geographical Sciences, 20: 569580.

Liu S, Sun R, Sun Z, Li X, Liu C. 2006. Evaluation of three complementary relationship approaches for evapotranspiration over the Yellow River basin. Hydrological Processes, 20: 2347-2361.

Lu J, Li ZL, Tang R, Tang BH, Wu H, Yang F, Labed J, Zhou G. 2013. Evaluating the SEBS-estimated evaporative fraction from MODIS data for a complex underlying surface. Hydrological Processes, 27: 3139-3149.

Marshall M, Tu K, Funk C, Michaelsen J, Williams P, Williams C, Ardö J, Boucher M, Cappelaere B, Grandcourt Ad. 2013. Improving operational land surface model canopy evapotranspiration in Africa using a direct remote sensing approach. Hydrology and Earth System Sciences, 17: 1079-1091.

Matin MA, Bourque CP-A. 2013. Assessing spatiotemporal variation in actual evapotranspiration for semi-arid watersheds in northwest China: Evaluation of two complementary-based methods. Journal of Hydrology, 486: 455-465.

McCabe M, Wood E, Su H, Vinukollu R, Ferguson C, Su Z. 2011. Multisensor Global Retrievals of Evapotranspiration for Climate Studies Using the Surface Energy Budget System. In: Land Remote Sensing and Global Environmental Change, Springer, pp: 747-778. 
Monin A, Obukhov A. 1954. Basic laws of turbulent mixing in the surface layer of the atmosphere. Contrib. Geophys. Inst. Acad. Sci. USSR, 151: 163-187.

Monteith J. 1965. Evaporation and environment. In: Symp. Soc. Exp. Biol, pp: 205-234.

Muthuwatta L, Bos M, Rientjes T. 2010. Assessment of water availability and consumption in the Karkheh River basin, Iran-using remote sensing and geo-statistics. Water Resources Management, 24: 459-484.

Oguntunde PG. 2004. Evapotranspiration and complimentarity relations in the water balance of the Volta Basin: Field measurements and GIS-based regional estimates. Bonn.

Penman H. 1956. Evaporation: an introductory survey. Neth. J. Agric. Sci, 4: 9-29.

Priestley C, Taylor R. 1972. On the assessment of surface heat flux and evaporation using large-scale parameters. Monthly weather review, 100: 81-92.

Qureshi AS, McCornick PG, Sarwar A, Sharma BR. 2010. Challenges and prospects of sustainable groundwater management in the Indus Basin, Pakistan. Water Resources Management, 24: 1551-1569.

Ren J-l, Li Q-f, Yu M-x, Li H-y. 2012. Variation trends of meteorological variables and their impacts on potential evaporation in Hailar region. Water Science and Engineering, 5: 137-144.

Rodell M, Houser P, Jambor Uea, Gottschalck J, Mitchell K, Meng C, Arsenault K, Cosgrove B, Radakovich J, Bosilovich M. 2004. The global land data assimilation system. Bulletin of the American Meteorological Society, 85: 381-394.

Rwasoka D, Gumindoga W, Gwenzi J. 2011. Estimation of actual evapotranspiration using the Surface Energy Balance System (SEBS) algorithm in the Upper Manyame catchment in Zimbabwe. Physics and Chemistry of the Earth, Parts A/B/C, 36: 736746.

Sarwar A, Bill R. 2007. Mapping evapotranspiration in the Indus Basin using ASTER data. International Journal of Remote Sensing, 28: 5037-5046.

Shifa YB. 2011. Estimation of Evapotranspiration Using Advection Aridity Approach. M.Sc Thesis, University of Twente, The Netherland.

Su H, Wood E, McCabe M, Su Z. 2007. Evaluation of remotely sensed evapotranspiration over the CEOP EOP-1 reference sites. Meteorological Society of Japan, 85: 439-459.

Su Z. 2002. The Surface Energy Balance System (SEBS) for estimation of turbulent heat fluxes. Hydrology and Earth System Sciences, 6: 85-99. 
Ullah MK, Habib Z, Muhammad S. 2001. Spatial distribution of reference and potential evapotranspiration across the Indus Basin Irrigation Systems. In: Pakistan country series no.8, Working paper 24, IWMI, pp: 55.

Usman M, Liedl R, Shahid MA. 2014. Managing Irrigation Water by Yield and Water Productivity Assessment of a Rice-Wheat System Using Remote Sensing. Journal of Irrigation and Drainage Engineering.

van der Kwast J, Timmermans W, Gieske A, Su Z, Olioso A, Jia L, Elbers J, Karssenberg D, Jong Sd. 2009. Evaluation of the Surface Energy Balance System (SEBS) applied to ASTER imagery with flux-measurements at the SPARC 2004 site (Barrax, Spain). Hydrology and Earth System Sciences Discussions, 6: 1165-1196.

Wang Y, Li X, Tang S. 2013. Validation of the SEBS-derived sensible heat for FY3A/VIRR and TERRA/MODIS over an alpine grass region using LAS measurements. International journal of applied earth observation and geoinformation, 23: 226-233.

Xu C-Y, Singh V. 2005. Evaluation of three complementary relationship evapotranspiration models by water balance approach to estimate actual regional evapotranspiration in different climatic regions. Journal of Hydrology, 308: 105-121.

Yu W, Yang Y-C, Savitsky A, Alford D, Brown C, Wescoat J, Debowicz D, Robinson S. 2013. The Indus Basin of Pakistan: The Impacts of Climate Risks on Water and Agriculture. World Bank Publications.

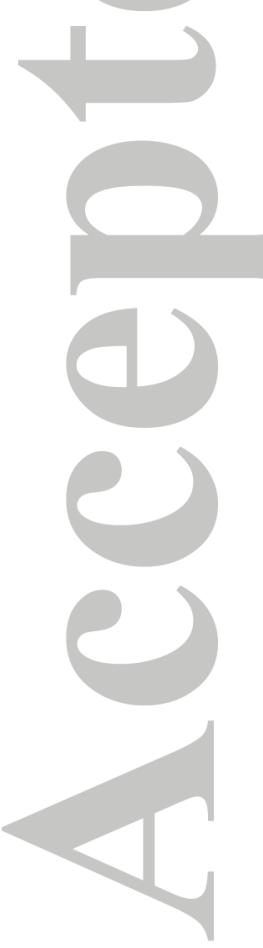




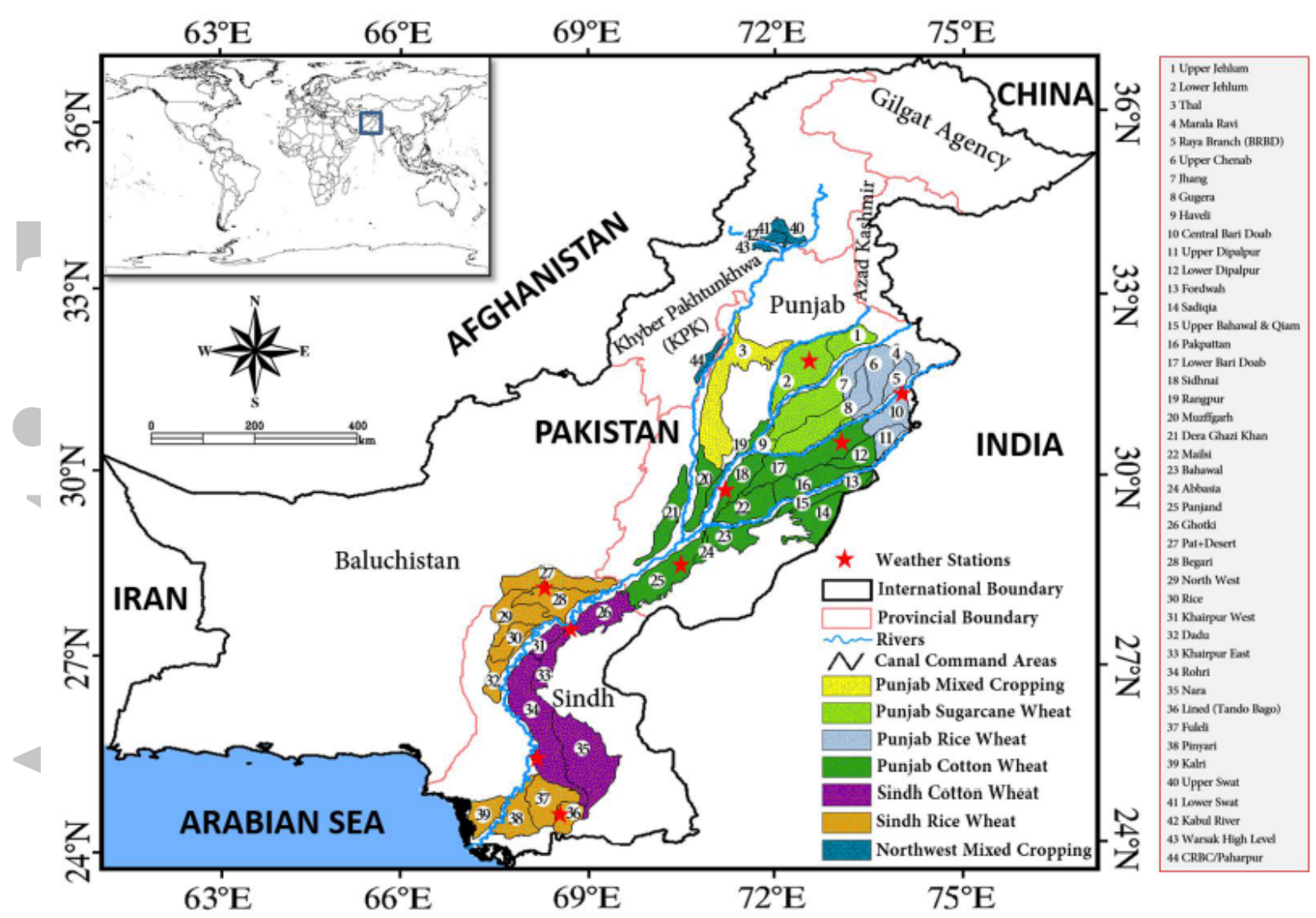

Figure 1: Location of the Indus Basin Irrigation System (IBIS) in Pakistan with weather stations, canal command areas (CCAs) and cropping zones.

Note: White encircled numbers represent the CCAs as mentioned on right side of the map.

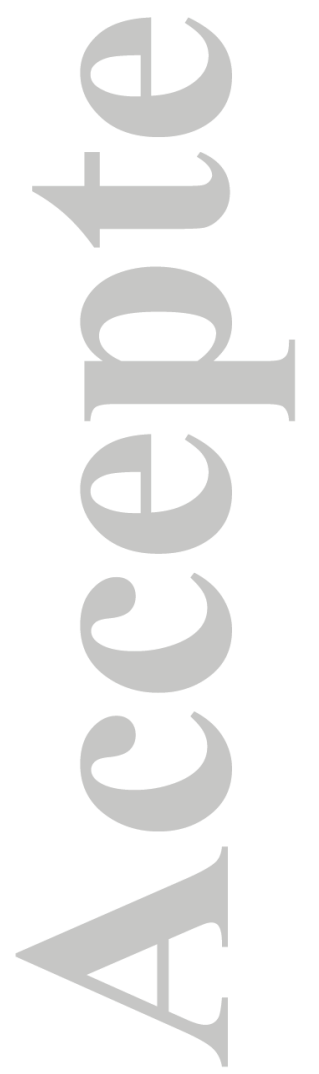

This article is protected by copyright. All rights reserved. 


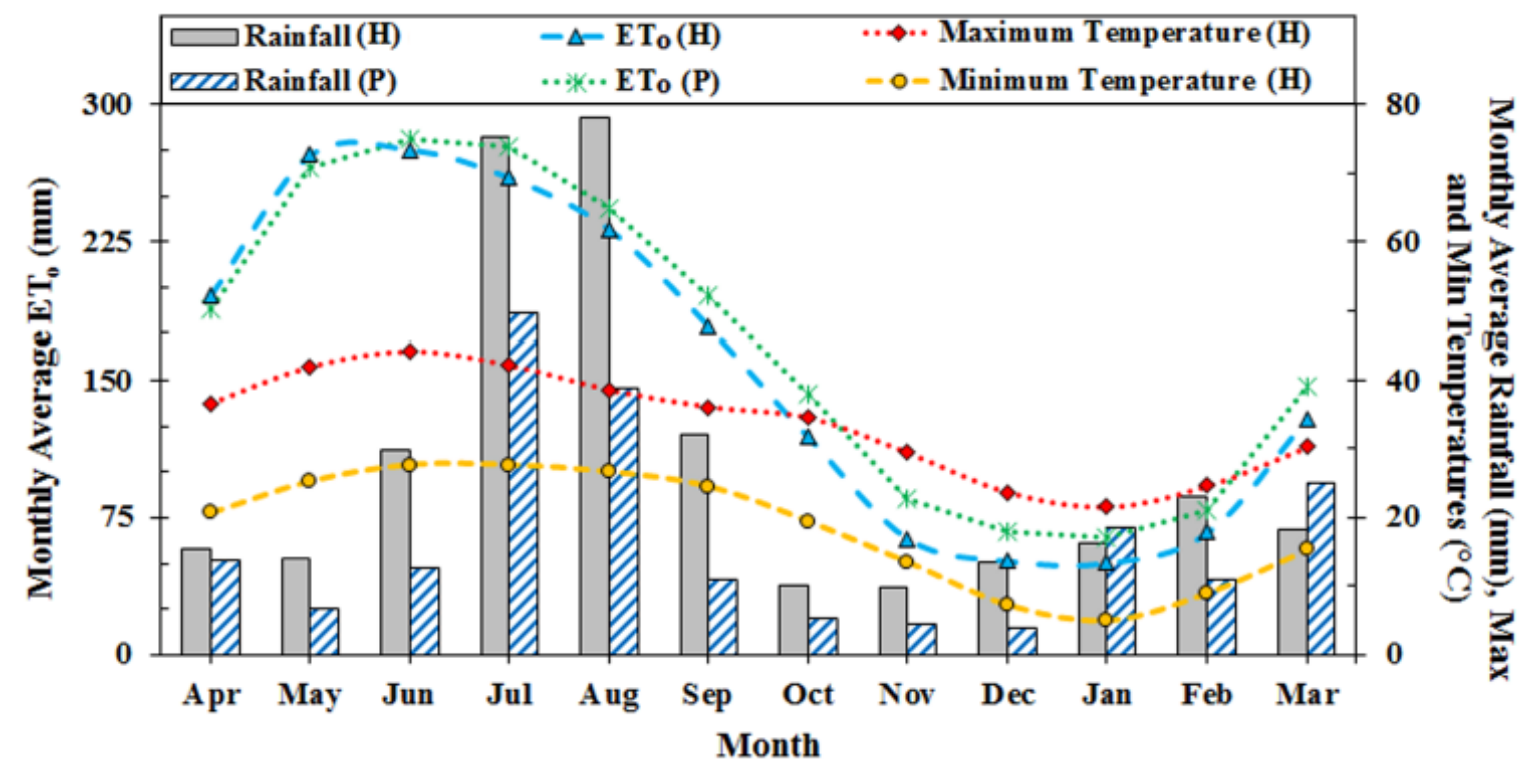

Figure 2: Distribution of reference ET (ETo), rainfall, minimum and maximum temperature in the IBIS for the study period [(P); April 2009-March 2010] in comparison with historical values [(H); 1980-2010].

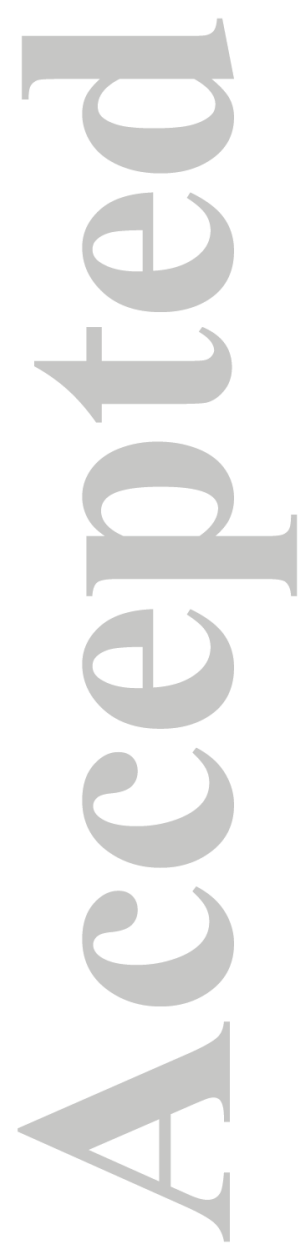

This article is protected by copyright. All rights reserved. 


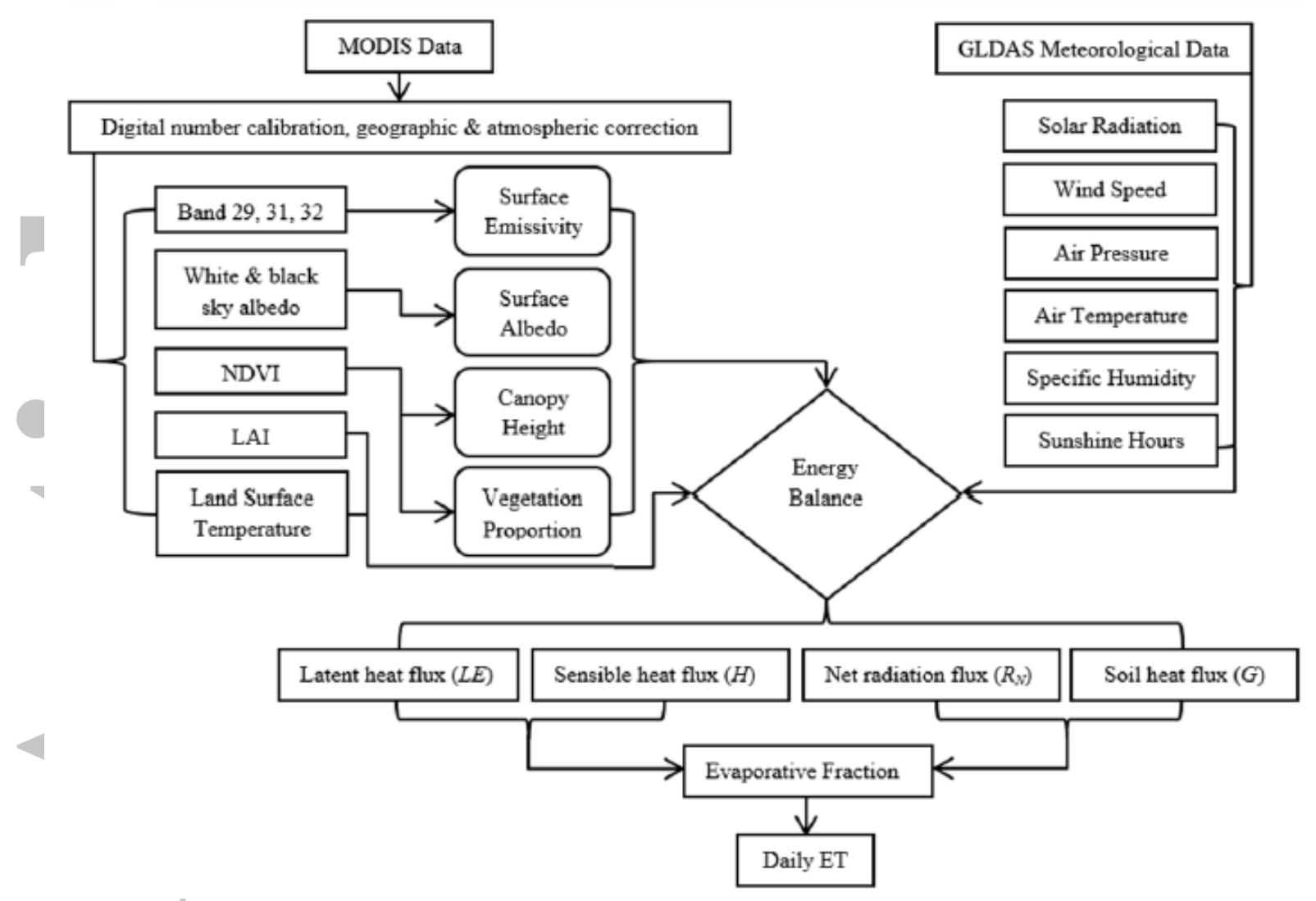

Figure 3: Flow chart summary for processing of MODIS and GLDAS data to force the SEBS algorithm.

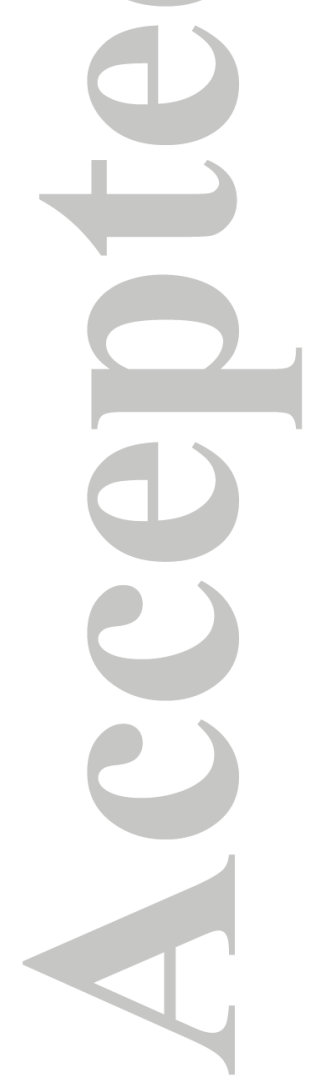

This article is protected by copyright. All rights reserved. 


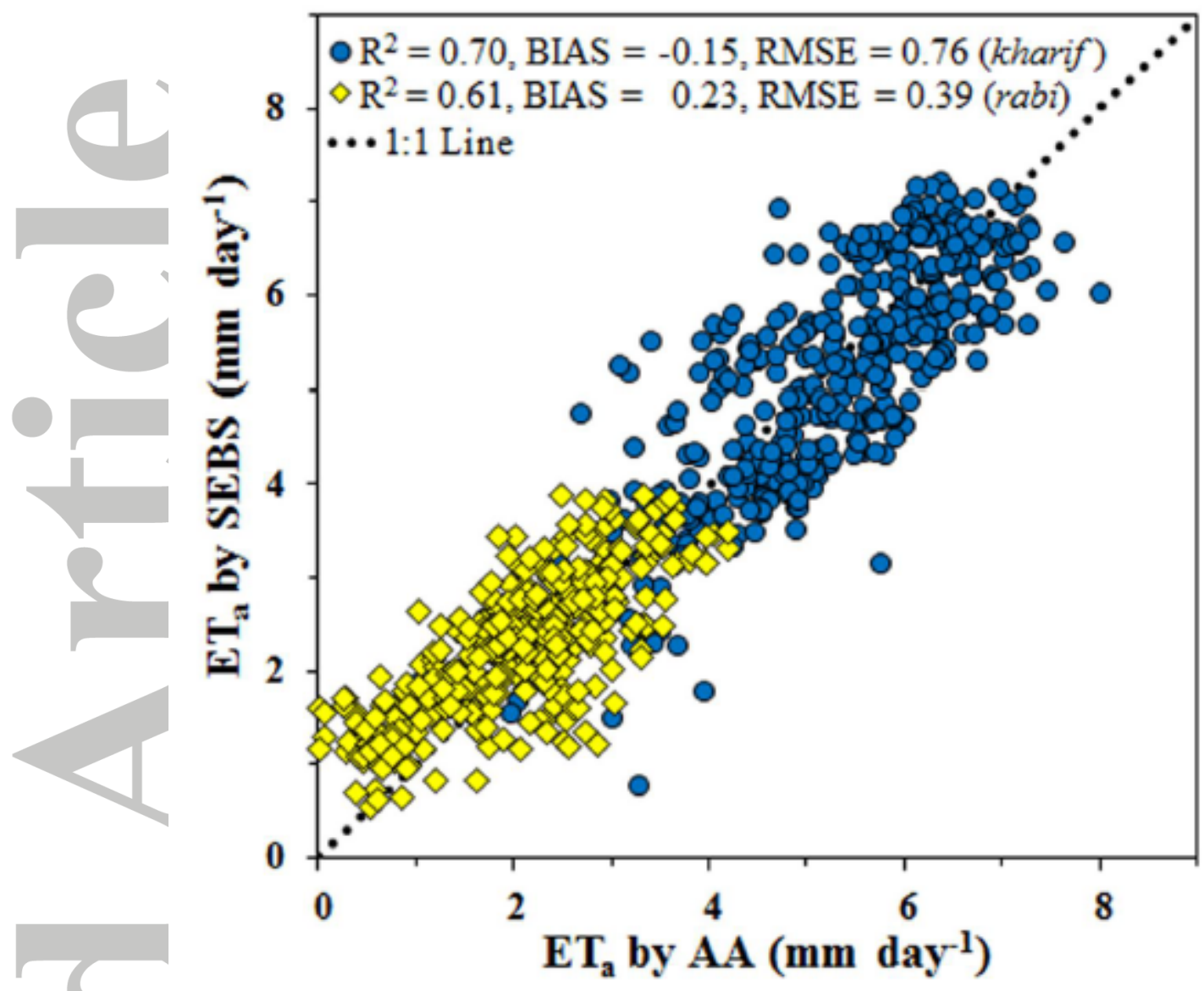

Figure 4: Comparison of SEBS estimated and Advection-aridity (AA) derived ETa during the kharif (April-September) season and the rabi (October-March) season. 

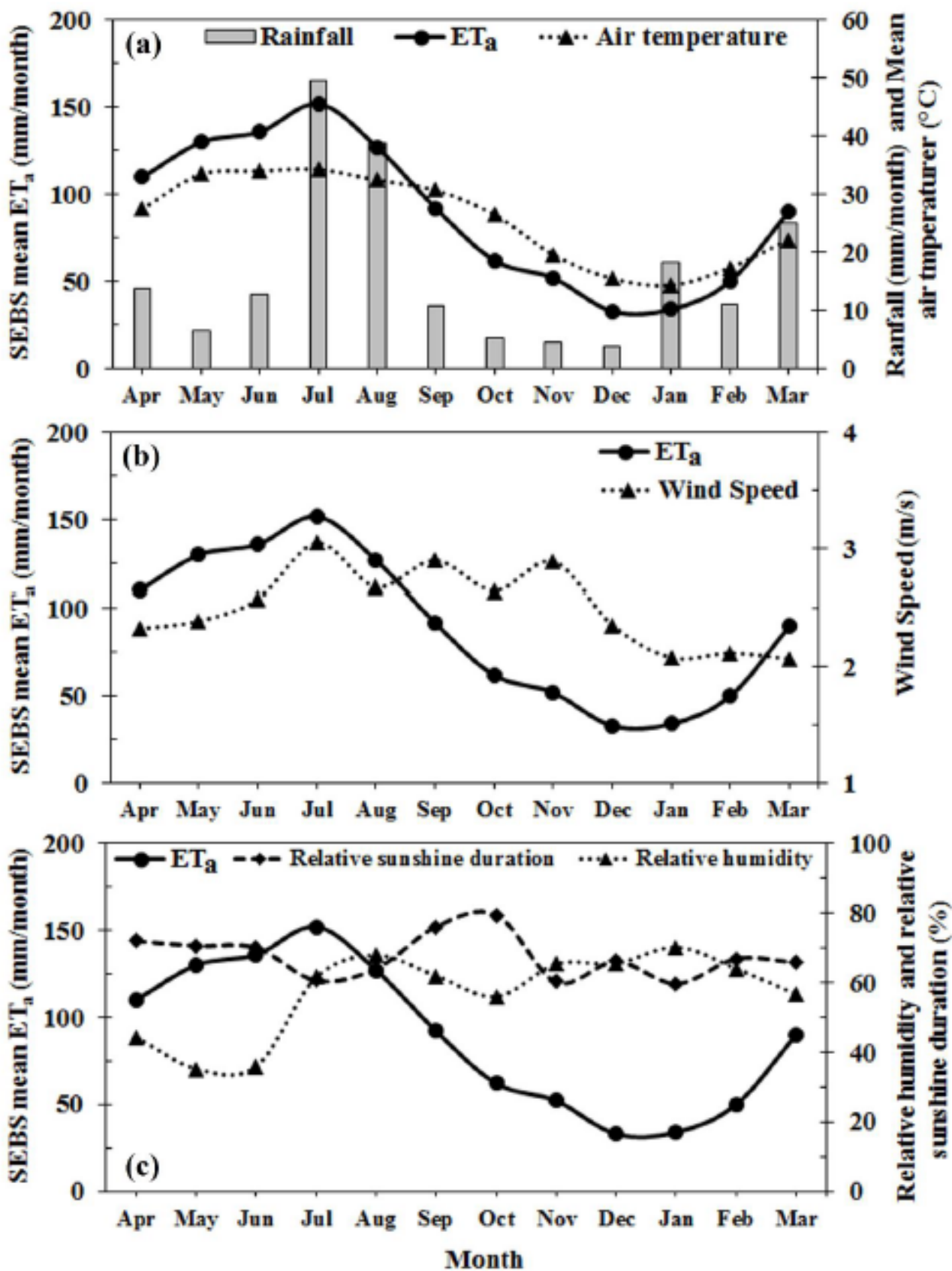

Figure 5: Effect of the climatic variables on SEBS estimated monthly ETa. 


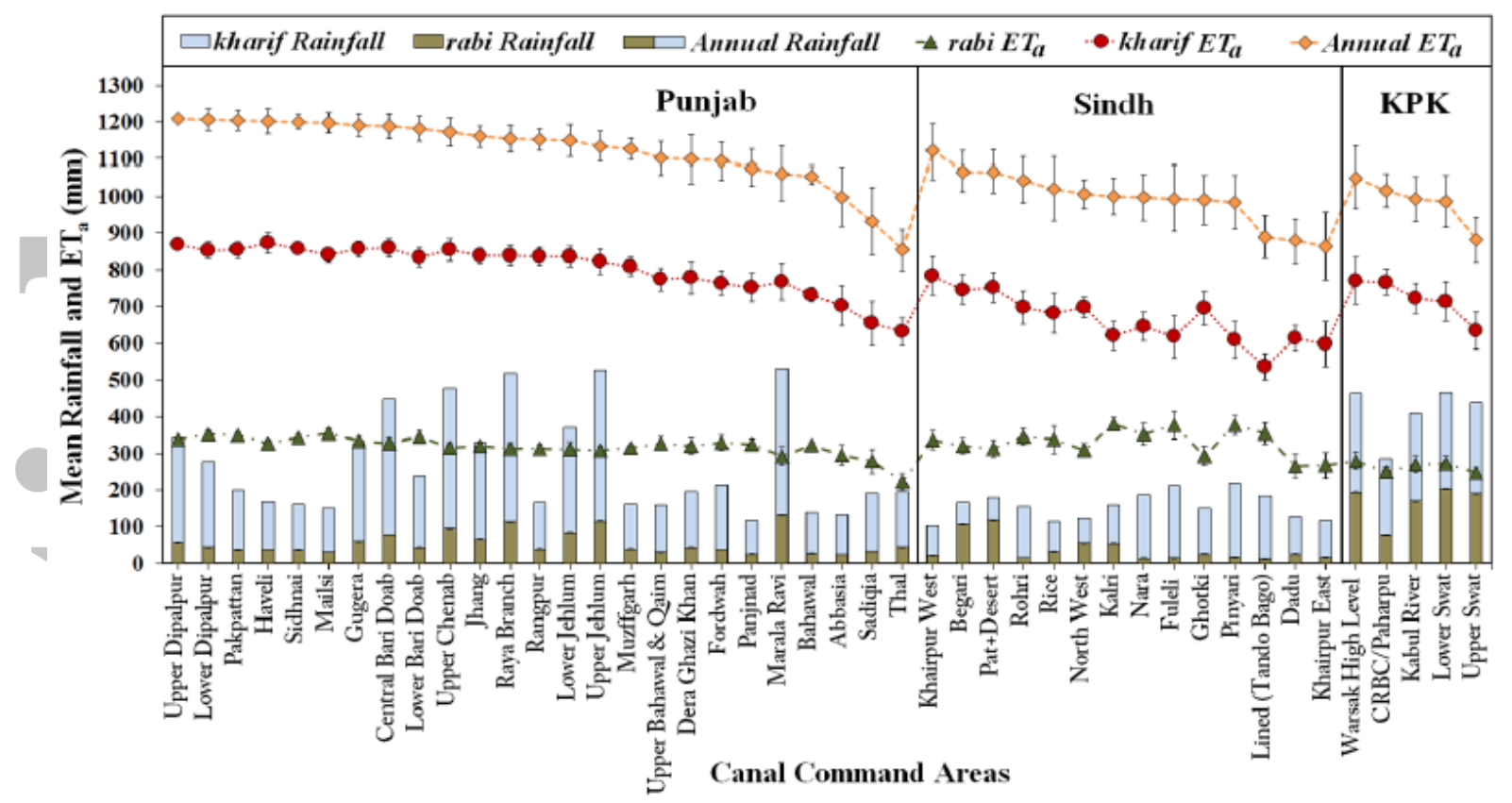

Figure 6: Mean seasonal and annual ETa $(\mathrm{mm})$ and rainfall $(\mathrm{mm})$ during the kharif (AprilSeptember) season and the rabi (October-March) season across each of the CCAs in the IBIS. (For the identification of the CCAs, the readers are referred to Figure 1.)

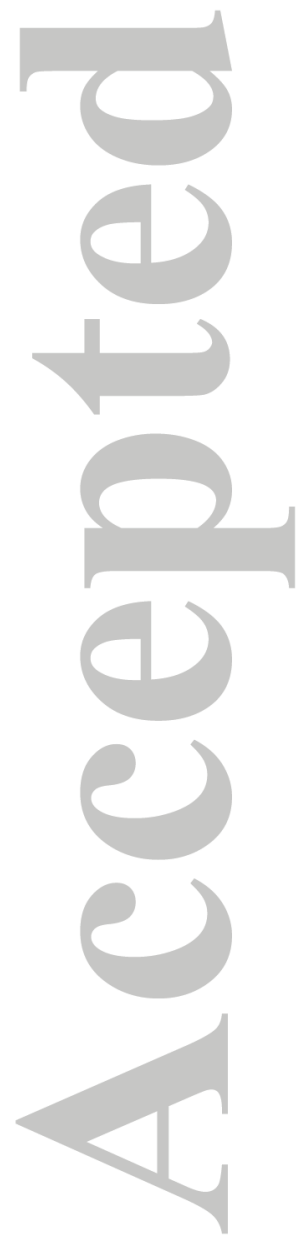

This article is protected by copyright. All rights reserved. 

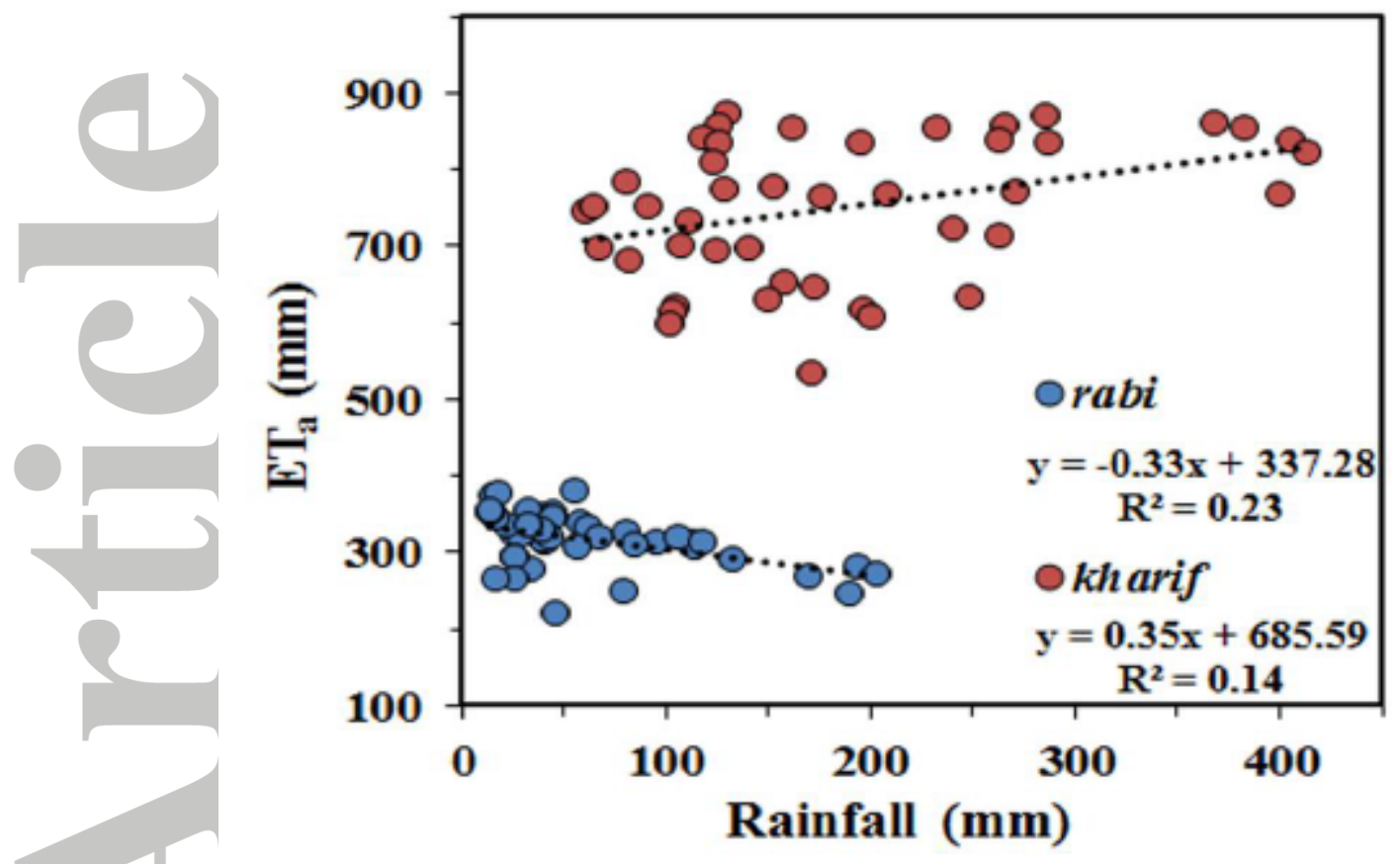

Figure 7: Correlation between mean seasonal rainfall and ETa across the CCAs in the IBIS.

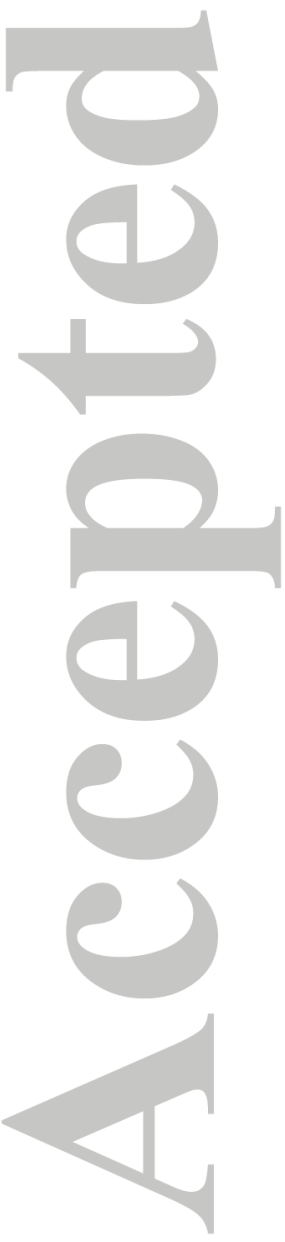




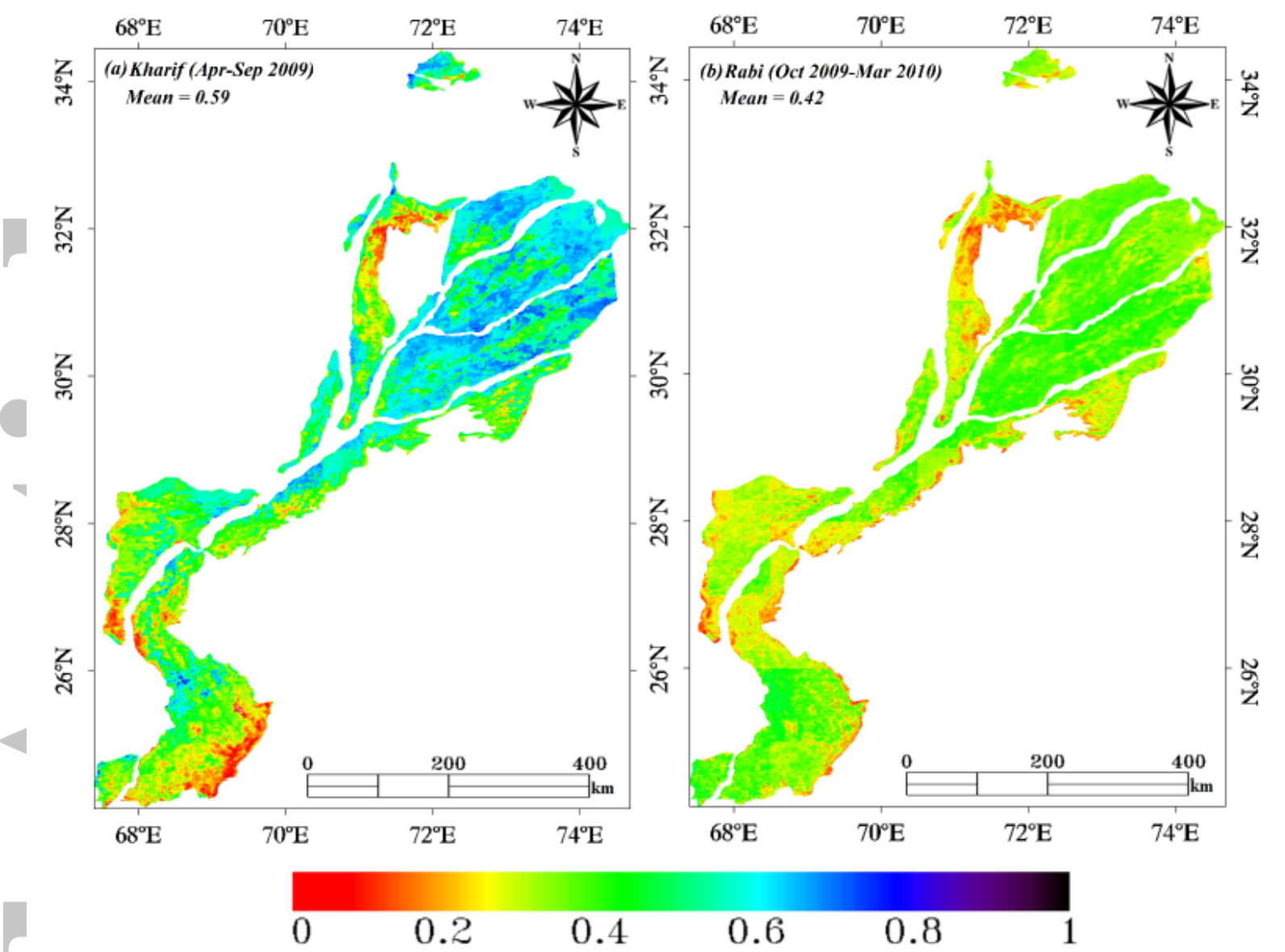

Figure 8: Spatial distribution of relative evapotranspiration (RET) as a ratio of $E T_{a} / E T_{p}$ in the IBIS. (For interpolation of the regions in this figure, readers are referred to Figure 1).

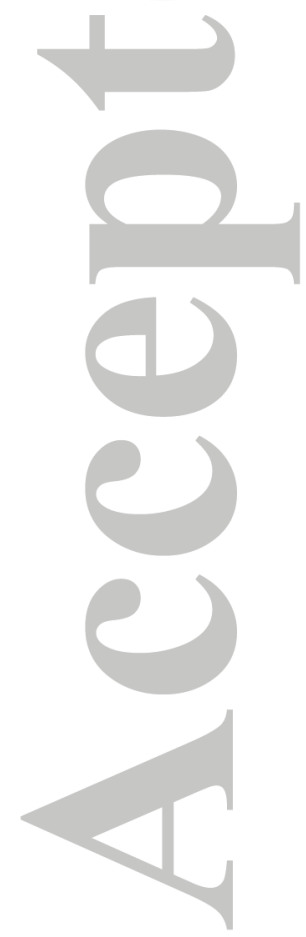

This article is protected by copyright. All rights reserved. 

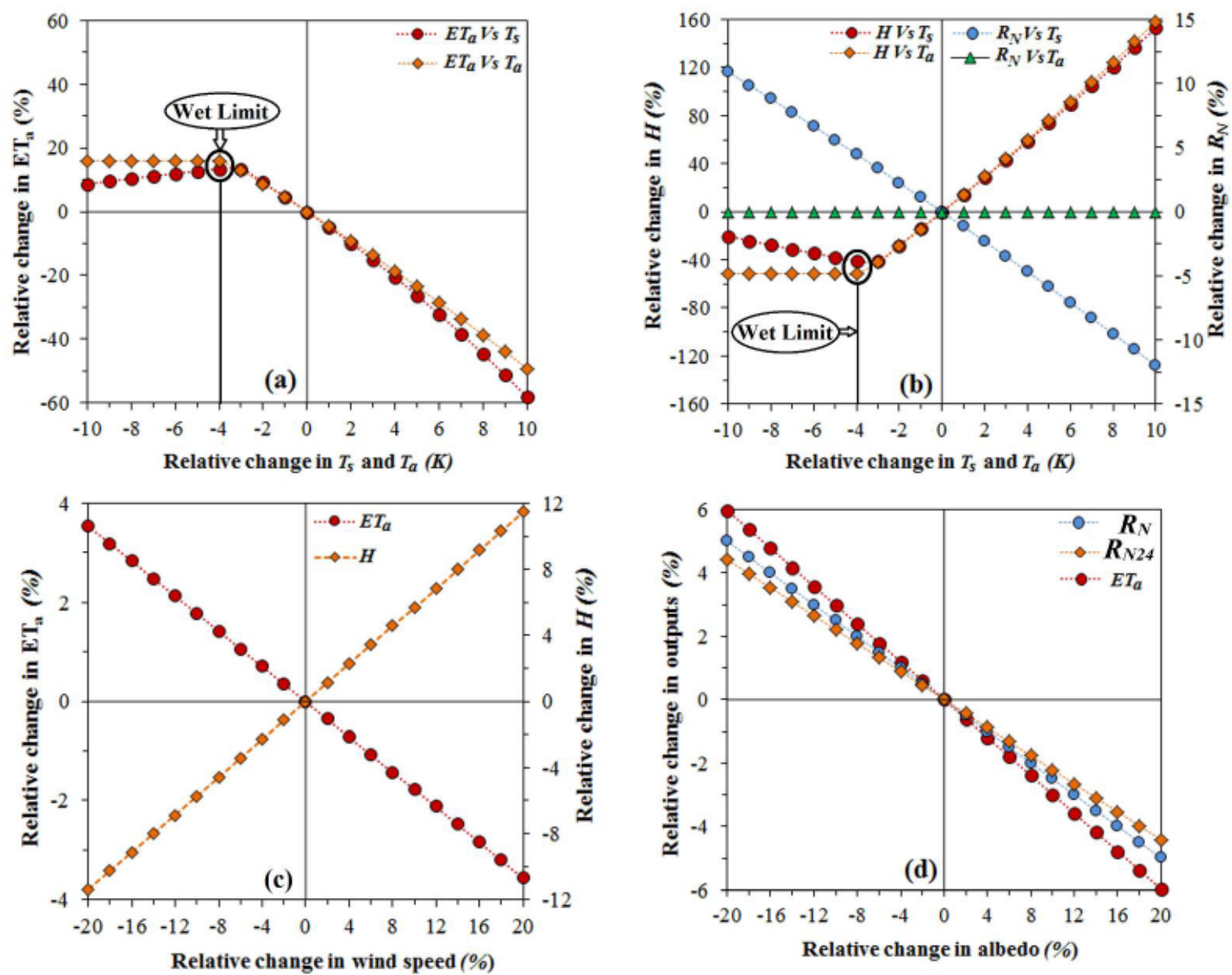

Figure 9: A sensitivity analysis on DOY-133 of SEBS estimated (a) ETa to change in $T_{s}$ and $T_{a}$ (b) Instant $R_{N}$ and $H$ to change in $T_{s}$ and $T_{a}$ (c) ETa, and $H$ to wind speed and (d) ETa, instantaneous $R_{N}$ and daily $R_{N 24}$ to change in albedo.

This article is protected by copyright. All rights reserved. 
Table 1. Cropping zones characteristics

\begin{tabular}{|c|c|c|c|c|c|c|c|c|}
\hline \multirow{2}{*}{ S.No } & \multirow{2}{*}{ Crop Zones } & \multirow{2}{*}{$\begin{array}{c}\text { Are } \\
\text { a } \\
(K \\
\left.\mathbf{m}^{2}\right)\end{array}$} & \multirow{2}{*}{$\begin{array}{l}\text { Ecolo } \\
\text { gical } \\
\text { Zone }\end{array}$} & \multirow{2}{*}{$\begin{array}{c}\text { Mean } \\
\text { Altitude } \\
\text { (m) }\end{array}$} & \multicolumn{2}{|c|}{$\begin{array}{c}\text { Temperatur } \\
\text { es }\end{array}$} & \multirow{2}{*}{$\begin{array}{c}\text { Rainfall } \\
\text { (mm) }\end{array}$} & \multirow{2}{*}{$\begin{array}{c}\text { Major Crop } \\
\text { Types }\end{array}$} \\
\hline & & & & & $\begin{array}{l}\text { Min } \\
(\mathrm{C})\end{array}$ & $\begin{array}{l}\text { Max } \\
\left({ }^{\circ} \mathrm{C}\right)\end{array}$ & & \\
\hline & $\begin{array}{l}\text { Punjab Mixed } \\
\text { Cropping }\end{array}$ & $\begin{array}{c}102 \\
90\end{array}$ & $\begin{array}{l}\text { Semi- } \\
\text { Arid }\end{array}$ & 163 & 6 & 43 & 222 & $\begin{array}{l}\text { Wheat, } \\
\text { Cotton and } \\
\text { Sugarcane }\end{array}$ \\
\hline & $\begin{array}{l}\text { Punjab Rice } \\
\text { Wheat }\end{array}$ & $\begin{array}{c}146 \\
73\end{array}$ & $\begin{array}{l}\text { Semi- } \\
\text { Arid }\end{array}$ & 173 & 4 & 44 & 423 & $\begin{array}{l}\text { Rice and } \\
\text { Wheat }\end{array}$ \\
\hline & $\begin{array}{l}\text { Punjab Cotton } \\
\text { Wheat }\end{array}$ & $\begin{array}{c}451 \\
85\end{array}$ & Arid & 323 & 6 & 46 & 152 & $\begin{array}{l}\text { Cotton and } \\
\text { wheat }\end{array}$ \\
\hline & $\begin{array}{l}\text { Sugarcane } \\
\text { Wheat }\end{array}$ & $\begin{array}{c}204 \\
83\end{array}$ & $\begin{array}{l}\text { Semi- } \\
\text { Arid }\end{array}$ & 200 & 6 & 45 & 321 & $\begin{array}{l}\text { Sugarcane } \\
\text { and wheat }\end{array}$ \\
\hline & $\begin{array}{l}\text { Sindh Cotton } \\
\text { Wheat }\end{array}$ & $\begin{array}{c}258 \\
76\end{array}$ & $\begin{array}{l}\text { Semi- } \\
\text { Arid }\end{array}$ & 125 & 10 & 48 & 123 & $\begin{array}{l}\text { Cotton and } \\
\text { wheat }\end{array}$ \\
\hline & $\begin{array}{l}\text { Sindh Rice } \\
\text { Wheat }\end{array}$ & $\begin{array}{c}287 \\
93\end{array}$ & $\begin{array}{l}\text { Semi- } \\
\text { Arid }\end{array}$ & 28 & 14 & 42 & 146 & $\begin{array}{l}\text { Rice and } \\
\text { Wheat }\end{array}$ \\
\hline & $\begin{array}{l}\text { Northwest } \\
\text { Mixed } \\
\text { Cropping }\end{array}$ & $\begin{array}{c}359 \\
3\end{array}$ & $\begin{array}{l}\text { Subtro } \\
\text { pical }\end{array}$ & 31 & 3 & 39 & 481 & $\begin{array}{c}\text { Wheat, Maize } \\
\text { and } \\
\text { vegetables }\end{array}$ \\
\hline
\end{tabular}


Table 2. Sources of data acquisition for SEBS algorithm

\begin{tabular}{|c|c|c|c|c|}
\hline Data Type & Source & Variables & Spatial Resolution & Temporal Resolution \\
\hline \multirow{4}{*}{$\begin{array}{c}\text { Satellite } \\
\text { Land } \\
\text { Surface } \\
\text { Data }\end{array}$} & \multirow{4}{*}{ MODIS } & LST/Emissivity (MOD11A1) & $1 \mathrm{~km}$ & Instantaneous \\
\hline & & Albedo (MCD43B3) & $1 \mathrm{~km}$ & 8-day \\
\hline & & LAI (MCD15A2) & $1 \mathrm{~km}$ & 8-day \\
\hline & & NDVI (MOD13A2) & $1 \mathrm{~km}$ & 16-day \\
\hline & GTOPO30 & DEM & $1 \mathrm{~km}$ & --- \\
\hline GLDAs & NOAH & $\begin{array}{c}\text { Wind Speed }(\mathrm{m} / \mathrm{s}) \\
\text { Air Pressure }(\mathrm{Pa}) \\
\text { Air Temperature }(\mathrm{K}) \\
\text { Specific Humidity }(\mathrm{Kg} / \mathrm{Kg}) \\
\text { Short-wave Radiation }\left(\mathrm{W} / \mathrm{m}^{2}\right) \\
\text { Long-wave Radiation }\left(\mathrm{W} / \mathrm{m}^{2}\right)\end{array}$ & $25 \mathrm{~km}$ & 3- Hourly \\
\hline
\end{tabular}

Table 3. Statistics $(Y=a x+b)$ between SEBS estimated mean monthly $\mathbf{E T}_{\mathbf{a}}(\mathrm{mm})$ and meteorological variables in the IBIS

\begin{tabular}{|c|c|c|c|c|c|}
\hline \multirow{2}{*}{ Statistics } & \multicolumn{5}{|c|}{ Meteorological variables } \\
\cline { 2 - 6 } & $\begin{array}{c}\text { Rainfall } \\
(\mathrm{mm})\end{array}$ & $\begin{array}{c}\text { Mean air } \\
\text { Temperature } \\
\left({ }^{\circ} \mathrm{C}\right)\end{array}$ & $\begin{array}{c}\text { Relative } \\
\text { sunshine } \\
\text { duration (\%) }\end{array}$ & $\begin{array}{c}\text { Relative } \\
\text { humidity (\%) }\end{array}$ & $\begin{array}{c}\text { Wind speed } \\
(\mathrm{m} / \mathrm{s})\end{array}$ \\
\hline $\mathbf{a}$ & 1.69 & 5.21 & 0.65 & -1.99 & 51.80 \\
\hline $\mathbf{b}$ & 60.81 & -44.24 & 45.32 & 202.11 & -40.90 \\
\hline $\mathbf{R}^{\mathbf{2}}$ & 0.33 & 0.86 & 0.01 & 0.32 & 0.17 \\
\hline $\boldsymbol{p}$-value & $0.049^{*}$ & $0.001^{*}$ & $0.768^{\mathrm{NS}}$ & $0.054^{\mathrm{NS}}$ & $0.160^{\mathrm{NS}}$ \\
\hline
\end{tabular}

$p$-value with Pearson linear correlation

NS indicates non-significant difference at the 0.05 probability level.

* Indicates significance at the 0.05 probability level. 
Table 4. Mean seasonal and annual rainfall $(R), \mathrm{ET}_{\mathrm{p}}(\mathrm{P}-\mathrm{T})$ and $\mathrm{ET}_{\mathrm{a}}(\mathrm{SEBS})$ during the Kharif (April-September) season and the rabi (October-March) season for different cropping zones in the IBIS. All units are in $\mathbf{m m}$.

\begin{tabular}{|l|l|c|c|c|c|c|c|c|c|c|c|c|}
\hline \multicolumn{1}{|c|}{$\begin{array}{c}\text { Crop } \\
\text { Zones }\end{array}$} & $R$ & $\mathrm{ET}_{\mathrm{a}}$ & $\mathrm{ET}_{\mathrm{p}}$ & $\begin{array}{l}\mathrm{ET}_{\mathrm{a}} \\
-R\end{array}$ & $R$ & $\mathrm{ET}_{\mathrm{a}}$ & $\mathrm{ET}_{\mathrm{p}}$ & $\begin{array}{c}\mathrm{ET}_{\mathrm{a}} \\
-R\end{array}$ & $R$ & $\mathrm{ET}_{\mathrm{a}}$ & $\mathrm{ET}_{\mathrm{p}}$ & $\begin{array}{c}\mathrm{ET}_{\mathrm{a}} \\
-R\end{array}$ \\
\cline { 2 - 13 } $\begin{array}{l}\text { Punjab } \\
\text { Cropping }\end{array}$ & 170 & 631 & 1131 & 461 & 52 & 222 & 797 & 170 & 222 & 853 & 1928 & 631 \\
\hline $\begin{array}{l}\text { Punjab } \\
\text { Rice } \\
\text { Wheat }\end{array}$ & 346 & 849 & 1096 & 503 & 77 & 319 & 740 & 242 & 423 & 1168 & 1836 & 745 \\
\hline $\begin{array}{l}\text { Punjab } \\
\text { Cotton } \\
\text { Wheat }\end{array}$ & 126 & 793 & 1106 & 667 & 26 & 329 & 808 & 303 & 152 & 1122 & 1914 & 970 \\
\hline $\begin{array}{l}\text { Punjab } \\
\text { Sugarcane } \\
\text { Wheat }\end{array}$ & 257 & 843 & 1109 & 586 & 64 & 322 & 760 & 258 & 321 & 1165 & 1869 & 844 \\
\hline $\begin{array}{l}\text { Sindh } \\
\text { Cotton } \\
\text { Wheat }\end{array}$ & 116 & 675 & 1017 & 559 & 7 & 335 & 913 & 328 & 123 & 1010 & 1930 & 887 \\
\hline $\begin{array}{l}\text { Sindh } \\
\text { Rice } \\
\text { Wheat }\end{array}$ & 103 & 667 & 1045 & 564 & 43 & 338 & 922 & 295 & 146 & 1005 & 1967 & 859 \\
\hline $\begin{array}{l}\text { Northwest } \\
\text { Mixed } \\
\text { Cropping }\end{array}$ & 295 & 701 & 1043 & 406 & 186 & 259 & 745 & 73 & 481 & 960 & 1788 & 479 \\
\hline
\end{tabular}

